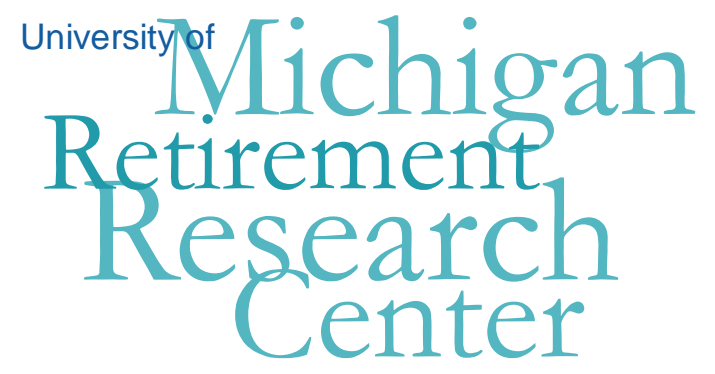

Working Paper

WP 2010-237

\title{
Occupational Learning, Financial Knowledge, and the Accumulation of Retirement Wealth
}

Brooke Helppie, Kandice A. Kapinos and Robert J. Willis

\begin{tabular}{|l|l|}
\hline $\mathrm{M}$ & $\mathrm{R}$ \\
\hline $\mathrm{R}$ & $\mathrm{C}$ \\
\hline
\end{tabular}

Project \#: UM10-08 


\title{
Occupational Learning, Financial Knowledge, and the Accumulation of Retirement Wealth
}

\author{
Brooke Helppie \\ University of Michigan \\ Kandice A. Kapinos \\ University of Michigan \\ Robert J. Willis \\ University of Michigan
}

October 2010

\author{
Michigan Retirement Research Center \\ University of Michigan \\ P.O. Box 1248 \\ Ann Arbor, MI 48104 \\ http://www.mrrc.isr.umich.edu/
}

(734) 615-0422

\section{Acknowledgements}

This work was supported by a grant from the Social Security Administration through the Michigan Retirement Research Center (Grant \# 10-M-98362-5-01). The findings and conclusions expressed are solely those of the author and do not represent the views of the Social Security Administration, any agency of the Federal government, or the Michigan Retirement Research Center.

Regents of the University of Michigan

Julia Donovan Darrow, Ann Arbor; Laurence B. Deitch, Bingham Farms; Denise Ilitch, Bingham Farms; Olivia P. Maynard, Goodrich; Andrea Fischer Newman, Ann Arbor; Andrew C. Richner, Grosse Pointe Park; S. Martin Taylor, Gross Pointe Farms; Katherine E. White, Ann Arbor; Mary Sue Coleman, ex officio 


\title{
Occupational Learning, Financial Knowledge, and the Accumulation of Retirement Wealth
}

\begin{abstract}
This study explores the relationship between general human capital investment, financial knowledge, occupational spillovers, and the accumulation of wealth in a primarily descriptive manner. Drawing upon human capital theory and following previous related work by Delavande, Rohwedder and Willis (2008), we hypothesized that individuals with daily exposure to financial knowledge through their occupation would benefit by having greater financial knowledge that would translate into greater wealth accumulation than individuals who do not enjoy such spillovers from their occupation. Using data from the Cognitive Economics Study and the Health and Retirement Study, we find strong evidence that individuals in financial occupations tend to have greater financial knowledge and moderate evidence that they also have greater wealth accumulation.
\end{abstract}

\section{Authors’ Acknowledgements}

This work was supported by a grant from the Social Security Administration through the Michigan Retirement Research Center (Grant \# 10-M-98362-5-01). We also acknowledge support for the research in this paper from NIA program project grant P01AG026571. The findings and conclusions expressed are solely those of the author and do not represent the views of the Social Security Administration, any agency of the Federal government, or the Michigan Retirement Research Center. 


\section{Introduction}

Even before the current economic crisis, there has been an explosion of interest in evidence that many Americans lack even rudimentary “financial literacy” (Lusardi and Mitchell, 2007, 2007a, 2007b; Lusardi, Mitchell, and Curto, 2009). Moreover, there is considerable cross-sectional evidence that low levels of literacy are correlated with a variety of poor economic outcomes (McArdle, Smith and Willis, 2009; Smith, McArdle and Willis, 2010). This evidence has created interest in the question of whether it would be possible to improve the economic welfare of ordinary Americans by increasing their financial literacy through informational campaigns, formal education or other means.

In this paper, we utilize a human capital theory of the acquisition of financial knowledge over the life cycle developed by Delavande, Rohwedder and Willis (2008) as a framework to interpret the crosssectional relationship between financial literacy and wealth using unusually rich bodies of data from the Cognitive Economics Survey (CogEcon) and the Health and Retirement Study (HRS). Within a human capital framework, it is useful to distinguish three terms - financial literacy, financial knowledge and financial capability — that are often used interchangeably but are conceptually distinct from a theoretical point of view and lend themselves to different measurement approaches. Financial literacy is commonly measured by an individual's performance on test items concerning financial knowledge or ability to do calculations that are relevant to financial decisions. While performance on a financial literacy test may provide a measure of the latent variable, financial knowledge, it is important to recognize that teaching people the correct answer to test items is unlikely to have much impact on their financial decisionmaking. In this paper, we view "financial knowledge," as a stock of human capital that may be augmented through purposive investment activities. In addition to deliberate investment activities, an individual's financial knowledge may be affected by "spillovers” from family, social and occupational exposures.

While financial knowledge is an important input into financial decision-making, knowledge alone is not sufficient for a person to make good financial decisions. Financial knowledge, together with other factors such as effort, attention, self-control, conscientiousness, and capacity to plan contribute to an 
individual’s “financial capability” which is revealed by behavior. ${ }^{1}$ In preparing for retirement, a financially capable person forms a saving plan that allows for adequate retirement wealth; modifies the plan as circumstances change; accumulates savings in an efficiently diversified portfolio using low cost, efficient and trustworthy financial institutions and good tax planning. As retirement approaches, a financially capable person chooses the best age to claim Social Security, manages retirement wealth by selecting financial products that deal with risks of health and longevity, but maintains sufficient flexibility to deal with other contingencies that may arise. Although financial capability leads, in principle, to observable outcomes, it is difficult, in practice, to disentangle capability from preferences, expectations and luck. For example, a lucky person may have become wealthy despite violating conventional wisdom about portfolio diversification; two equally capable people who differ in risk preference or bequest motive may accumulate different amounts of wealth and choose different portfolio composition of stocks and bonds; a person may begin claiming Social Security at age 62 because of a belief that his or her personal mortality risk is higher than actuarial rates or because he or she fails to understand that benefits would be higher if the claiming age is delayed. Despite these theoretical differences in these concepts and because we do not actually observe one's stock of financial knowledge, we utilize a financial literacy score as our proxy for financial knowledge in our empirical work.

It is also important to recognize that the benefits of financial knowledge may accrue to a household to the extent that husbands and wives share household income and wealth. As Hsu (2010) argues, this creates the basis for a household division of labor in which one partner specializes in acquiring financial knowledge and manages the family’s finances while the other specializes in acquiring the knowledge to carry out other household tasks. In most of our analysis in this paper we will consider the household as the unit of analysis but, when appropriate, we use measures of the characteristics and abilities of the "financial respondent," the partner deemed most financially knowledgeable in response to

\footnotetext{
${ }^{1}$ This term is introduced in the name of the "National Financial Capability Study," a survey conducted by FINRA with support from the United States Department of Treasury (http://www.sec.gov/spotlight/invadvcomm/finranationalfinancialcapabilitystudy.pdf). Our definition of the term is not necessarily what the survey designers had in mind. (The survey design team was led by Annamaria Lusardi; Robert Willis served as a consultant.)
} 
the question: "Which member of your immediate family is most knowledgeable about your family’s assets, debts, and retirement planning?”2

In this paper, we explore the correlates of financial knowledge with particular attention to the role of exposure to financial or investment activities through one's occupation. We examine whether individuals with this exposure, which we also refer to as an occupational spillover, have more financial knowledge and hence, greater wealth accumulation than individuals in other occupations. Because of the complexities of these relationships, our work represents a first step in answering these questions, but does not offer a conclusive causal story.

\section{Life Cycle Accumulation of Financial Knowledge}

We draw on a simple human capital model of the acquisition of financial knowledge presented in Delavande, Rohwedder and Willis (2008)—denoted hereafter as DRW—-to provide a framework for the empirical analysis of this paper. In their model, financial knowledge is a particular type of human capital that is acquired over the life cycle by means of investment in learning about matters that affect a household's ability to manage its income, expenditures and savings effectively and efficiently in service of maximizing its expected lifetime utility. Individuals need financial knowledge to manage day-to-day matters such as budgeting, shopping for the lowest price, paying bills, balancing a checking account, and using a credit card. It is also needed in pursuit of long-run goals including housing, children's education and having access to sufficient resources during retirement. Understanding issues such as compound interest, knowledge of the risks and returns of alternative investments, benefits of risk diversification, options for mortgage finance, tax law, trustworthiness and costs of alternative financial and credit institutions, etc., helps individuals achieve these goals.

\footnotetext{
${ }^{2}$ For single respondents and those in partnerships where they are not planning a joint financial future, each respondent is the financial respondent for his or her own household. For couples in which more than one member completed a survey, the financial respondent was designated using the question "Which member of your immediate family is most knowledgeable about your family's assets, debts and retirement planning?” (This is the same question as is used in the Health and Retirement Study to designate a financial respondent.) Where one person was not at least weakly indicated to be the financial respondent, we used an algorithm to choose a financial respondent. In this algorithm, we used the answer to a question about who makes financial decisions, how many objective sources of financial information were used to complete the survey, who had more of the most common asset types, and who refused to answer fewer questions about the amount of wealth. In cases where a financial respondent was still not clearly indicated ( $<5 \%$ of households), we randomly assigned financial respondent status.
} 
The timing and volume of investment depends on the balance between the benefits of additional financial knowledge and the cost of acquisition. In the DRW model, investment in financial knowledge is governed by a human capital production function in which an individual combines his or her cognitive ability, stock of knowledge, purchased inputs and effort in order to acquire additional knowledge. ${ }^{3}$ The productivity per unit of time spent investing in financial knowledge is greater for people with greater ability or a higher stock of knowledge. Depending on how ability and knowledge affect the opportunity cost of time, more able and knowledgeable people may face either higher or lower costs of learning relative to those with lesser ability and knowledge.

Assume that an additional unit of financial knowledge yields a benefit of $b$ percent per dollar of a financial transaction per period. For example, focusing on expected returns on a retirement wealth portfolio, assume that an additional unit of financial knowledge would enable an individual obtain a return that is closer to the efficient mean-variance frontier. Thus, holding risk constant, the additional financial knowledge would enable the person to obtain an expected return of $(1+b) r$ on a portfolio that previously had a return of $r$ percent. The additional return might come about through improved diversification, by choosing a financial services provider with lower fees or by selecting a better financial advisor. The total value of the unit of knowledge depends on its durability—knowledge may be forgotten or become obsolete — and the length of time that it is applied — the investor may be young or old and a financial investment may be held for a long or a short time. Most importantly, the total value of the investment depends on the number of dollars to which it is applied. An extra percentage point of return is worth only ten dollars per year on a one thousand dollar portfolio, but is worth ten thousand dollars per year on a million dollar portfolio.

This scale economy associated with investment in financial knowledge is a general characteristic of any human capital decision in which the cost of acquiring knowledge is independent of its future rate

\footnotetext{
${ }^{3}$ Current theories of cognitive ability distinguish between "fluid intelligence" — the ability to think and reason-and "crystallized intelligence" - the amount of knowledge a person possesses. (For details see Cattell, 1987, and McArdle and Woodcock,1998) DRW and Smith, McArdle and Willis (2010) discuss the parallels between human capital theory and the theory of fluid and crystallized intelligence.
} 
of utilization. The non-convexities caused by scale economies create an incentive for knowledge (or crystallized intelligence) to become specialized and for a household division of labor in which one spouse tends to specialize on financial matters (Becker, 1991; Hsu, 2010). This is true for the full range of household financial decisions, including shopping for the lowest price and best quality for household consumption goods; managing the household budget and credit cards; choosing the most advantageous means of financing home purchases; planning for retirement by selecting an appropriate savings rate, choosing an efficient portfolio, understanding pension plans, etc. Because the knowledge that is relevant to these various domains differs, there is room for specialization between the spouses in domain-specific financial knowledge.

In addition, this scale economy creates an incentive to acquire financial knowledge that is greater the larger the volume of resources to which the knowledge will be applied. Since higher lifetime income is positively correlated with consumption, savings and wealth, the demand for financial knowledge will tend to be higher for high-income households. To the extent that such households acquire more financial knowledge and that knowledge is productive in enhancing their economic outcomes, the correlation between economic well-being and financial knowledge will be reinforced. Because of feedback loops over the life cycle between economic resources and incentives to invest in financial knowledge, it is difficult to estimate the productivity of these investments.

While deliberate attempts to learn about financial matters are surely important, it is likely that a significant amount of the information—accurate or inaccurate—-that people that have in their minds about finance is the result of spillovers from the social interactions they have in their personal and work lives. In this paper, we will examine the role of occupational spillovers on people’s financial knowledge and financial outcomes. Individuals tend to make occupational choices at relatively early ages and it is implausible that the differential opportunity to acquire useful financial knowledge on the job sways many people to choose a job in banking or finance rather than in medical technology or engineering. Although it is tempting to think that occupational spillovers might offer a possible way to estimate how productive financial knowledge is for financial outcomes of people at later ages, it also plausible to suppose that 
individuals who find financial matters more interesting or discover an aptitude for finance while they are in school will be relatively more likely to choose occupations such as banking or finance than those who have an interest in and aptitude for topics unrelated to finance. Thus, we prefer to think of the analysis in this paper as primarily descriptive rather than causal.

\section{Cognitive Economics Study Data and Analysis}

We use data from the CogUSA Study and the Cognitive Economics Study for our first set of analyses. Jack McArdle, a cognitive psychologist, started the CogUSA study in 2006 with the goal of conducting extensive cognitive tests and gathering rich demographic and health data on a nationally representative sample of older Americans.

The Cognitive Economics Study (CogEcon) is a mail and web-based survey project designed by a group of economists from the Survey Research Center at the University of Michigan. ${ }^{4}$ The CogEcon study was developed to explore the relationship between cognitive measures and a variety of economic variables including many measures of financial knowledge, detailed wealth holdings and information about financial decision-making. The first CogEcon survey was fielded in 2008 to 1,222 eligible CogUSA respondents. The final response rate was 80.8 percent, with 987 respondents having submitted completed surveys. A second "post-crash” survey was designed and fielded to 939 eligible CogEcon respondents ${ }^{5}$ in 2009 with a 90.2 percent response rate.

We use linked data from the CogUSA and CogEcon studies to create a unique dataset that includes detailed background information on respondents, demographics, cognitive measures, financial knowledge measures, and reported wealth holdings. From CogUSA, we use demographic variables including age and sex, background information including educational attainment, longest-held occupation and self-employment status, and standardized "number series score,” a cognitive measure of fluid

\footnotetext{
${ }^{4}$ The CogEcon survey (NIA P01AG026571) was led by Robert Willis and Matthew Shapiro with help from Daniel Benjamin, Andrew Caplin, Miles Kimball, Kathleen McGarry, Claudia Sahm, and Tyler Shumway. Gwen Fisher, Brooke Helppie, and Joanne Hsu oversaw the internet and mail data collection in addition to providing help with survey design.

${ }^{5}$ Respondents to the 2008 survey who were terminally ill, were no longer cognitively or physically able to complete a survey, or who had withdrawn from the study were not invited to complete the 2009 survey.
} 
intelligence from the Woodcock Johnson Psychoeducational Test Battery. ${ }^{6}$ From the CogEcon study, we use several measures of financial knowledge and financial outcomes, including measures of wealth and portfolio composition.

\subsection{Sample}

For the individual-level analysis, we use data from CogEcon 2008 respondents for whom we have sex, age, educational background, number of economics courses, and who completed at least one question in the financial sophistication test battery $(n=903)$. For analyses requiring information about occupation, we further restrict the sample to the 869 individuals who have ever worked and for whom we have information about their longest-held occupation. Finally, for analyses investigating respondents’ understanding of how stock and bond rates of returns compare, we restrict to 669 individuals who have non-missing values for this question.

Table 1 shows some of the characteristics of the respective samples of individuals. The demographics are quite similar across the three samples. The samples are about 53 percent female, about 29 percent single with a mean age of around 64 years at the time of the first CogUSA interview in 2007. Number series scores within the CogEcon sample are still close to a standard normal distribution, so a 1unit increase in number series score represents a roughly one standard deviation increase in fluid intelligence. The average education level of across all samples is approximately 14.5 years and the average number of economics courses taken is approximately 1.3, but over 59 percent of our sample did not take any economics courses. We discuss the financial knowledge and occupation variables below.

For the household-level analysis, we include all singles who completed the CogUSA and CogEcon 2008 surveys and couples for which we have CogUSA data (including education, sex, age, cognitive measures and occupation) for both members of the couple and in which at least one member of the couple completed the CogEcon 2008 survey. $^{7}$ The household sample is about fifty percent singles and

\footnotetext{
${ }^{6}$ We have re-normalized the scores to a $\sim \mathrm{N}(0,1)$ distribution on the CogUSA sample, so a 1-unit increase in our number series measure represents a one standard deviation increase in measured fluid intelligence among our sample.

${ }^{7}$ If both members of a couple both completed the CogEcon 2008 survey, their data are only used once in the analysis.
} 
fifty percent couples, and is approximately 500 observations for most regressions, depending on item response rates. ${ }^{8}$

In all regression analyses, we use sampling weights that were developed to make CogUSA mirror the Health and Retirement Study population. ${ }^{9}$ All reported standard errors are therefore weighted and heteroskedasticity-robust.

\subsubsection{Measures of financial knowledge}

One goal of the Cognitive Economics Study was to provide measures of financial knowledge at a more sophisticated level than is available in the Health and Retirement Study and other nationally representative studies. In the 2008 baseline survey, respondents answered a 27-item battery of questions aimed at measuring financial knowledge. This battery of questions included 25 statements to be rated by respondents on a 12-point scale as “surely false” to "surely true.” Each respondent was randomly assigned to see either a "true" version or a "false" version of each of the 25 true/false statements. Additionally, the battery included two multiple-choice items about rates of return.

We have subjectively separated these 27 questions into two groups: 11 questions that we label as “attitudinal and 16 questions that we label as “factual” (see Appendix A for the complete list of questions). The "attitudinal” questions reflect common wisdom that, at least prior to the crash, was accepted by most financial specialists. One example of a "true” statement included in our "attitudinal" measure is "Financially, investing in the stock market is better than buying lottery tickets." At least through the fielding period of our baseline CogEcon survey in 2008, this statement would generally have been regarded as true. However, in general, these questions reflect normative beliefs or attitudes about financial concepts. The "factual” financial knowledge questions are more positive (as opposed to normative) and tend to be mathematical or definitional in nature, and include statements that would not generally be considered controversial, even after the events of the past two years. An example of a true

\footnotetext{
${ }^{8}$ For analyses using the 2009 Post-Crash CogEcon survey question about the historical rate of return on stocks versus bonds, the sample is further restricted to as low as 377 observations because of survey nonresponse

${ }^{9}$ We currently use individual-level weights in all analyses. When household weights are developed for the CogEcon sample we will use them for analyses that use household-level data.
} 
"factual” statement in the financial knowledge test battery is "Mutual funds do not pay a guaranteed rate of return." 10

Finally, in the 2009 survey, we asked whether respondents thought that the rate of return on stocks over the past 100 years had exceeded that on bonds, been equal, or had been less than the return on bonds. We view this question as ascertaining whether respondents are aware of the historical "equity premium” in the return to stocks, as compared to bonds. We use this as a third proxy for financial knowledge or sophistication.

From these measures, we have created three separate measures of financial sophistication. The first measure, "Factual Financial Knowledge," is a standardized $(\sim N(0,1))$ mean score for the 16 “factual” questions about financial matters. The second measure, “Attitudinal Financial Knowledge,” is a standardized mean score for the 11 attitudinal questions about financial matters. The third measure, “Equity Premium Awareness,” is an indicator variable equal to one for the 67\% of respondents who responded (correctly) that the rate of return on stocks has exceeded that on bonds over the past century, and zero otherwise.

\subsubsection{Measures of wealth and portfolio allocation}

The other important goal of the Cognitive Economics Study was to gather detailed information about wealth holdings and portfolio allocations. In this paper, we use several measures of wealth and portfolio allocation to examine the relationship between occupational spillovers into financial knowledge and economic outcomes. First, we use a household measure of retirement wealth held in defined contribution plans and individual accounts. ${ }^{11}$ Second, we use a measure of "total household wealth," the sum of retirement wealth plus checking, savings, money market accounts, certificates of deposit, net real estate wealth, business and farm equity, stocks, bonds and other investments held outside of retirement

\footnotetext{
${ }^{10}$ The full list of questions used in the "attitudinal" and "factual” financial knowledge measures can be seen in Appendix A: Financial Knowledge Measurement.

${ }^{11}$ We used the following question from the CogEcon Survey: Do you (or your spouse/partner) hold any tax-advantaged retirement accounts, such as IRAs (both classic/ traditional and Roth IRAs), 401(k) or 403(b) plan accounts, or Keogh accounts? If so, what is the current balance / total value of these accounts?
} 
accounts, minus credit card debt. In our sample, the average total wealth is around $\$ 800,000$, with a standard deviation of \$1.9M. Third, we use an indicator variable that is equal to one if the respondent holds any wealth in stocks or stock mutual funds. Sixty-nine percent of households in our sample hold stock or stock mutual funds.

\subsubsection{Occupational classification}

Throughout this paper, we create several different "financial occupation” categorizations of the Census 2000 occupation codes from the respondents' longest-held jobs, where we aim to flag occupations that might have facilitated learning about financial topics.

First, we create an indicator variable, high financial, equal to one if the regular tasks for an occupation include conducting cost-benefit analyses, making investment decisions, and predicting rates of return. Examples of high financial occupations include high-level executives, financial managers, production managers, accountants, many kinds of analysts, and economists. Second, we create budget, which is equal to one if the occupation's tasks include managing resources and /or budgets prospectively. We expect that individuals in such occupations might have developed some skills related to discounting, understanding opportunity costs, and saving by living within a budget. This variable, budget, includes high- and lower-level executives and managers, business operations specialists, financial specialists, actuaries, economists, clergy, designers, producers and directors. Third, we flag occupations that require frequent use of mathematical knowledge common in working with interest rates, exponents, present values, and rates of return as high math. We hypothesize that individuals in such occupations may have an advantage in understanding the value of compounding, growth, and discounting future values, and thus have an easier time creating projections for their own future. Examples include accountants and auditors, computer scientists and systems analysts, actuaries, mathematicians, statisticians, other mathematical scientists, engineers, astronomers and physicists, chemists and material scientists, economists, and statistical assistants.

Figure 1 illustrates the relationship between these variables for one respondent per household included in our household-level sample. If any of the above variables (high financial, budget, or high 
math) are equal to one, a composite variable called financial occupation indicator is set equal to one, and zero otherwise. In the diagram, the union of the three indicators represents this composite variable. Note that these are not mutually exclusive categorizations, but our intent is to use both narrow and broad definitions of being in a financial occupation to investigate financial knowledge spillovers.

As a last indicator of an occupation dealing with financially related content at work, we create a "lower bar financial occupation indicator," which is equal to one if the occupation deals with any financial content, and zero if the likelihood of financial learning in the occupation is arbitrarily close to zero. Common examples of occupations in which individuals are very unlikely to have been exposed to financial content include registered nurses, teacher assistants, customer service representatives and truck drivers. In this measure, secondary school teachers are coded as possibly having been exposed to financial content, as are low level retail sales managers and secretaries or administrative assistants. These occupations are also coded as zeros under our composite financial occupation indicator, because it seemed that most individuals in these occupations would not have been exposed to significant amounts of high-level budgeting, math, or financial tasks over the course of their jobs.

Figure 2 shows the relationships between the lower-bar and financial occupation indicators. The lower-bar financial occupation indicator (mostly) contains all of the financial occupation indicators from the combination of the three categories described above. This lower bar indicator is a much broader indicator of financial knowledge exposure at work, as over half of our sample falls into such an occupation, whereas only about a quarter of the sample are categorized as having worked in an occupation with high level financially-related content.

Table 2 summarizes the relationship between our financial knowledge occupation exposure indicators and our measures of financial knowledge. For each occupation categorization, we present the mean financial knowledge score for individuals who were in the occupational group or not in it. That is, the first row gives the means for those for whom their longest-held occupation may have had budget content (that is, for whom budget=1), while the second row gives the means for those whose longest-held occupations were not classified as having budget content (that is, for whom budget $=0$ ). From these 
simple descriptive statistics, we find that on average, individuals whose longest-held occupation may have involved financial content display higher levels of financial knowledge. ${ }^{12}$ Not surprisingly, we also find that our broader categorization, lower-bar financial occupation, yields lower financial knowledge scores on average than our narrower categorizations, such as budget, high math, or high financial.

\subsection{What influences financial knowledge and occupational sorting?}

First, we hypothesize that the accumulation of financial knowledge is consistent with the basic model of human capital accumulation described earlier in this paper. That is, we expect that years of education and the number of economics courses will be positively correlated with financial knowledge. Table 3 shows the pair wise correlations between our financial knowledge measures, education and fluid intelligence. As expected, our three different measures of financial knowledge are all positively correlated with each other and with our human capital measures.

In Table 4, we present results examining the partial correlations between financial knowledge, education and ability using linear regressions of the form:

$$
F K_{i}=\alpha+\beta_{1} \text { ed }+\beta_{2} \text { econ courses }+X_{i} \Gamma+\varepsilon_{i}
$$

where $X_{i}$ includes exogenous control variables including age in years, an indicator variable for whether female, and fluid intelligence as measured by the number series score. The dependent variables, denoted by FK in the equation above, are “factual” financial knowledge, “attitudinal” financial knowledge and awareness of the equity premium -- whether respondents thought that the real rate of return on stocks exceeded that on bonds over the last century. The first two dependent variables are standardized, so a one-unit increase represents a one-standard deviation increase in measured financial knowledge. The second is a binary variable that is equal to one if a respondent answered correctly that stocks have outperformed bonds over the last century. Again, we find a positive correlation between human capital and financial knowledge, but the number of economics courses may be more important than years of education: two economics courses are associated with a larger increase in financial

\footnotetext{
12 The fact that the means for "no" in the math occupations are not negative is an odd result of having normalized the financial sophistication scores.
} 
knowledge than an additional year of education (columns 2 and 3). Consistent with other studies of financial knowledge or financial literacy, age is negatively associated with two of our three measures of financial knowledge, as is being female (Lusardi and Mitchell, 2007; Hsu, 2010). As Hsu (2010) also finds, fluid intelligence is positively related to financial knowledge, perhaps due to a lower cost of acquiring an additional unit of financial knowledge. A standard deviation increase in fluid intelligence is associated with a 0.157 or 0.251 standard deviation increase in financial knowledge measures, respectively (columns 1 and 2, respectively). Column 3 shows that a standard deviation increase in fluid intelligence is also associated with a six percent higher chance that an individual is aware of the historical equity premium.

Next, we explore the extent to which education, economics courses and fluid intelligence are related to whether a respondent had worked in an occupation in which he or she might have had the opportunity to learn about financial matters. We expect that as the number of economics courses increases, individuals will be more likely to sort into finance-type occupations. Table 5 shows the results from a regression of the form

$$
\text { OCC }_{i}=\alpha+\beta_{1} \text { ed }+\beta_{2} \text { econ courses }+X_{i} \Gamma+\varepsilon_{i}
$$

where $O C C_{i}$ is one of our indicator variables for whether a respondent's occupation may have had financial content. The first three columns show the results from a linear probability model where the dependent variable is a zero/one indicator reflecting one of our three narrow categories of finance-related occupations: budget, high financial and high math, respectively. We also report results using our broader categorizations of occupational spillover in columns 4 and 5 (financial occupation indicator and lower bar, respectively). Regardless of how we categorize occupation as “financial,” years of education and number of economics courses are positively related to financial content on one's career. The lack of significance of number series, our measure of fluid intelligence, suggests that fluid intelligence has its primary effect on occupational choice through affecting the level and content of education. 


\subsection{Occupational spillovers and financial knowledge}

Next, we examine more directly whether working long term in a finance occupation is associated with greater financial knowledge, separate from educational background and ability. In this analysis, we focus on households because we expect that household financial knowledge matters more than individual level knowledge in understanding wealth accumulation and retirement planning. We control for lifetime earnings, because earnings are related to occupation and, based on our theoretical model, higher earnings should increase the incentive to acquire financial knowledge. Though we cannot make conclusive claims about causality in these analyses, we interpret our results as suggestive of spillover effects of occupation on financial knowledge and financial outcomes. The next three tables give the results from householdlevel regressions following the equation:

$$
F K_{i}=\alpha+Z^{\prime} \beta+X^{\prime} \Gamma+O C C^{\prime} \delta+\varepsilon_{i}
$$

As above, $X$ is a vector including exogenous variables including the maximum age of both members in the couple and the maximum number series score. In this household-level specification, $Z$ is a vector including the education levels of both the man and woman in a household, a "single" indicator variable, and the log of household lifetime earnings imputed from linked HRS-Social Security data files. ${ }^{13}$ Here, OCC includes the regressors of interest: budget, high financial, high, finance occupation indicator and our lower-bar. However, these are now set equal to one if either person in the household was in a finance-related occupation in their longest-held occupation.

We present results using our three measures of financial knowledge in Tables 6-8, respectively. In Table 6, the dependent variable is the “attitudinal” financial knowledge score of the household's financial respondent. ${ }^{14}$ Column 1 gives the results from the baseline regression, without the occupation variables. Both male and female education levels are positively related to "attitudinal” financial knowledge. In contrast to Table 4 (with individual level regressions), the coefficients on number series

\footnotetext{
${ }^{13}$ Individual earnings measures are imputed using occupation by age category and sex cell means from Health and Retirement Study Social Security earnings data. These are cell means of the present discounted value of lifetime earnings. Household-level lifetime earnings are created by summing the imputed lifetime earnings measures across both members of a couple, for members of couples. We present more detail about creation of the lifetime earnings measures used to create these imputations in the appendix.

${ }^{14}$ See footnote 2 .
} 
score and number of economics courses are no longer statistically significant. The coefficient on lifetime earnings is large and positive: a $1 \%$ increase in imputed lifetime household earnings is associated with a half a standard deviation increase in "attitudinal” financial knowledge. Columns 2 through 4 report the results from regressions of one of our occupation variables, budget, high math, or high financial, plus the full set of control variables, on "attitudinal” financial knowledge. We expect positive coefficients on these variables if there is a spillover effect of occupation on financial knowledge accumulation. Indeed, the coefficients on all three of the occupation indicators are positive and relatively large, implying that experience in occupations in which one might acquire financial knowledge or related skills are associated with a $0.251,0.183$, or 0.356 standard deviation increase in "attitudinal” financial knowledge. However, only those on budget and high financial content are statistically significant. Columns 4 and 5 report results from a regression of our composite indicator and our lower-bar indicator on "attitudinal” financial knowledge. The coefficient on the composite indicator is statistically significant, and implies a 0.27 standard deviation higher financial knowledge for households in which at least one member's longestheld occupation may have had some financial content. The coefficient on our lower-bar occupation indicator is smaller and not statistically significant, implying that it may be higher-level knowledge acquired through occupation that is related to our "attitudinal” financial knowledge measure.

In Table 7, the dependent variable is the "factual” financial knowledge score of the household's financial respondent. Interestingly, economics courses and fluid intelligence correlate positively with “factual” financial knowledge but they are insignificant in explaining "attitudinal” financial knowledge. Again, lifetime earnings are positively predictive of "factual” financial knowledge, though the magnitude is smaller than with "attitudinal” financial knowledge. The composite indicator finance occupation indicator and high math are positively related to "factual” financial knowledge. Consistent with the previous table, all coefficients on the occupation variables are positive and of relatively large magnitude, even though not all reach a standard level of statistical significance.

Table 8 reports the results of regressions where the dependent variable is equal to one if the financial respondent is aware that returns on stock have exceeded those on bonds over the last century, 
and zero otherwise. As with the other regressions, education and the number of economics courses are positively associated with knowledge of the equity premium. Lifetime earnings are also strongly and positively related to knowledge of the equity premium. Here as well, the coefficients on the occupation variables are all positive, although only one is statistically significant.

We interpret tables 6 through 8 as offering suggestive evidence that there may indeed be spillover effects of occupational learning on financial knowledge accumulation, even after controlling for fluid intelligence, education and lifetime earnings.

\subsection{Occupational spillovers and wealth accumulation}

A key question is whether the occupational spillovers in financial knowledge actually affect economic outcomes. In other words, does this exposure to financial concepts in one's occupation translate into greater wealth accumulation? In tables 9 through 11, we examine the relationship between wealth outcomes and occupation for evidence of occupational effect that are unrelated to earnings, ability or education. These regressions follow equation [4]:

$$
\text { financial outcome }=\alpha+Z^{\prime} \beta+X^{\prime} \Gamma+O C C^{\prime} \delta+\varepsilon
$$

This equation is parallel to equation [3], but the dependent variables are now the natural log of household retirement wealth, the natural log of total household wealth, and an indicator variable equal to one if the household holds any stock or stock mutual funds. Also as before, $X$ is comprised of household measures of age, sex and fluid intelligence (as measured by the number series score), and the vector $Z$ contains male and female education levels, a "single” indicator variable and the maximum number of economics courses taken by either member of the couple.

We present results using our three measures/indicators of household wealth in Tables 9-11, respectively. In Table 9, the dependent variable is the natural log of total household retirement wealth reported in the 2008 survey. Retirement wealth includes wealth held in 401(k) plans, other defined contribution pensions, individual retirement accounts (IRAs) and Keogh accounts. In cases where two members of the couple completed the 2008 CogEcon survey, we use the total household retirement holdings as reported by the financial respondent. Column 1 shows the results from the baseline 
regression. In this regression, a one percent increase in lifetime earnings is associated with a three percent increase in retirement wealth holdings. Number series score and education variables are also strongly positively related to retirement wealth holdings. A one standard deviation increase in number series score is associated with a 1.1 percent increase in retirement wealth holdings, while an additional year of education is associated with about a 0.25 percent increase in retirement wealth holdings. Columns 2 through 6 show similar results, but also include the finance-related occupation indicators. The coefficients on these indicators are consistently positive but not statistically significant. Their magnitudes indicate an association of a size comparable to one-half to one standard deviation of fluid intelligence.

The dependent variable in Table 10 is the log of total wealth, which includes retirement wealth, cash, checking, savings, certificates of deposit, net real estate holdings, and other stock and bond holdings, minus credit card debt. Again, column 1 shows the results of the baseline regression. Of note, the coefficients on lifetime earnings and the number series score are much smaller in magnitude. Columns 2 through 6 show that there are positive and but not statistically significant associations between the occupation indicators and total wealth, though smaller than in analyses where the dependent variable was retirement wealth. Here, the lower-bar occupation indicator has the largest coefficient and is the closest to being statistically significant.

Next, we examine whether having one member of the household in a finance occupation is associated with whether the household owns stock in Table 11. The dependent variable is an indicator variable of whether a household owns any stock or stock mutual funds. As in tables 9 and 10, the coefficients on lifetime earnings and number series score are positive and statistically significant. In contrast to the previous two tables, however, most of the coefficients on economics courses are statistically significant. Education also is positively and statistically significantly related to stock ownership. Columns 2 through 6 show the relationship between occupation and stock ownership. All but the high math coefficient are positive and large. We find some significant effects of being in a finance occupation using the composite finance-related occupation and budget indicators, which are associated 
with 13 to 15 percentage point higher probabilities of stock ownership, comparable to the effect of a two standard deviation increase in number series score.

Our analyses clearly illustrate that financial knowledge is related to educational level and economics course material, reflecting that financial knowledge may be acquired in those courses and/or that coursework in economics may be indicative of a general interest in the subject matter. We also find strong evidence of a link between working long term in a finance occupation and financial knowledge. However, we find only weak evidence using the CogEcon data that this translates in greater wealth. Nonetheless, examination of the estimated signs and magnitudes of our occupational indicators reveals that these are positive and of substantive magnitudes. Therefore, we may be failing to measure precisely these effects due to sample size limitations and errors in our occupational variable classifications. Additionally, because our imputed lifetime earnings measures depend on occupation, some of the effects of occupation and earnings may not be properly measured. To investigate further this last question of whether occupational exposure to financial content translates into greater wealth accumulation, we turn to the Health and Retirement Study.

\section{Health and Retirement Study Data and Analysis}

In the next section, we use data from the Health and Retirement Study (HRS) to seek support for our hypothesis that occupational spillovers may affect economic outcomes. The HRS provides a nationally representative sample of the US population of individuals over age 50 and includes rich data to study the economics and demography of aging. While the HRS lacks detailed measures of financial knowledge and fluid intelligence comparable to those available in the CogEcon data, a particular benefit of the HRS is that it offers a much larger sample size. A second important benefit of the HRS data is that they are linked to yearly Social Security earnings data. The Social Security data allows us to control for respondents' lifetime earnings directly instead of using imputed values as in our CogEcon analysis. ${ }^{15}$

\footnotetext{
${ }^{15}$ See Appendix B: Lifetime Earnings Measures for detail.
} 


\subsection{Sample and measures}

We focus our HRS analysis on married respondents linked to the SS earnings data and for whom we have at least 25 years of earnings data. This yields 2,534 households. We ascertain the predominant occupation for each spouse based on tenure in occupation. We use household level finance occupation indicators as we did for our CogEcon analysis (see Section 3.1.3). We also include the following control variables in estimating equation [4]: the natural log of the household lifetime earnings, a dichotomous variable equal to one if either spouse has zero lifetime earnings, the age, education, and self-employment status of both the husband and the wife. The self-employment variable is equal to one if the spouse was ever self-employed, and zero otherwise. This variable was unavailable in the CogEcon data, but seems important, as individuals may acquire high levels of financial knowledge and financial skills while running their own businesses. We use the RAND HRS measure of total household wealth excluding secondary residence. ${ }^{16}$ We present summary statistics of these variables for our sample in Table 12. Our HRS sample has slightly more "finance” occupation households and slightly less "math” occupation households than our CogEcon sample, but otherwise is quite similar on the fraction of households with at least one member in the finance occupations. The HRS sample is also slightly younger and slightly less educated.

\subsection{Results}

We present our main results using the HRS data in Table $13 .{ }^{17}$ We find that households where the longest-held occupation of at least one spouse may have included exposure to financial content have higher total household wealth on average. Our results are robust to whether we use household level measures of occupational spillover (as we did for the CogEcon analysis) or individual level and to different specifications of the spouses' education and age. Overall, the HRS coefficients are consistent in

\footnotetext{
${ }^{16}$ We use the h7atota variable, which includes net value of primary residence, net value of other real estate (not secondary residence), net value of vehicles, net value of businesses, net value of IRA, Keogh accounts, net value of stocks, mutual funds, and investment trusts, net value of checking, savings, or money market accounts, net value of CDs, government savings bonds, and T-bills, net value of bonds and bond funds, and net value of other savings, less value of primary mortgage, value of other home loans, and value of other debt.

${ }^{17}$ We also estimate Table 13 using "stock ownership" as the dependent variable. Those results are qualitatively consistent with those presented here and are available upon request.
} 
direction with the CogEcon findings but are more precisely estimated. We suspect this is due to the larger sample available in the HRS. Even though we are unable to control for some of the measures we include in the CogEcon specifications (e.g., number series score or number of economics courses), the HRS results strengthen our descriptive analysis by showing a strong association between occupational choice and household wealth.

\section{Conclusion}

In this study, we aimed to provide some preliminary and exploratory evidence about the relationships between general human capital investment, financial knowledge, occupational spillovers, and the accumulation of wealth. Drawing upon human capital theory and following previous related work by Delavande, Rohwedder and Willis (2008), we hypothesized that individuals with daily exposure to financial knowledge through their occupation would benefit by having greater financial knowledge that would translate into greater wealth accumulation than individuals who do not enjoy such spillovers from their occupation.

Using the CogEcon data, we find strong patterns of greater financial knowledge, as measured by financial literacy scores, for individuals who sort into occupations with at least some exposure to financial and investment content. Not surprisingly, taking more economics courses correlates positively with both financial knowledge and sorting into "finance" occupations. Although we are not able to disentangle the causal direction of these likely interdependent relationships, the finding that individuals in finance occupations seem to have greater financial knowledge is consistent with theories about financial knowledge and human capital acquisition (Delavande, Rohwedder, and Willis, 2008).

Finally, we find some suggestive evidence, which is admittedly stronger with the HRS data, that this occupational spillover (of financial concepts to one’s financial knowledge) may translate into greater wealth accumulation. Although these findings are preliminary and exploratory, the policy implication is that individuals do seem to benefit from greater financial literacy. 


\section{References}

Becker, Gary S. (1991). A Treatise on the Family. Cambridge, MA: Harvard University Press.

Cattell, Raymond B. (1987). Intelligence: Its structure, growth, and action. New York: Elsevier Science Pub. Co.

Delavande, Adeline; Rohwedder, Susann and Willis, Robert J. (2008) "Retirement Planning and the Role of Financial Literacy and Cognition.” Michigan Retirement Research Center Working Paper 2008190

Hsu, Joanne W. (2010). Aging and Strategic Learning: The Impact of Spousal Incentives on Financial Literacy. Dissertation Chapter.

Lusardi, Annamaria, and Olivia Mitchell. (2007). Financial Literacy and Retirement Preparedness: Evidence and Implications for Financial Education. Business Economics 42, no. 1 (January 22): 35-44 doi: $10.2145 / 20070104$.

. (2007a). Financial Literacy and Retirement Planning: New Evidence from the Rand American Life Panel. Pension Research Council Working Paper WP2007-3. . (2007b). Baby Boomer retirement security: The roles of planning, financial literacy, and housing wealth. Journal of Monetary Economics 54, no. 1 (January): 205-224.

doi:10.1016/j.jmoneco.2006.12.001.

Lusardi, A., Mitchell, O. S. and Curto, V. (2009). Financial literacy among the young: Evidence and implications for consumer policy. National Bureau of Economic Research Working Paper Series No. 15352.

McArdle, John.J. and Richard W. Woodcock (eds.). 1998. Human abilities in theory and practice. Mahwah, NJ: Erlbaum.

McArdle, J. J., Smith, J. P. and Willis, R. J. (2009). Cognition and economic outcomes in the health and retirement survey. National Bureau of Economic Research Working Paper Series No. 15266.

RAND HRS Data, V. 2008. Produced by the RAND Center for the Study of Aging, with funding from the National Institute on Aging and the Social Security Administration. Santa Monica, CA.

Smith, J. P., McArdle, J.J., and Willis, R.J. (2010). "Financial decision making and cognition in a family context.” RAND Working Paper Series WR-785. 
Table 1: Descriptive Statistics: Individual-level Sample from CogEcon and CogUSA

\begin{tabular}{|c|c|c|c|c|}
\hline Analyses including: & & $\frac{\frac{\text { Financial }}{\text { Knowledge }}}{\frac{\text { Measures }}{\text { col. } 1}}$ & $\frac{\frac{\text { Financial }}{\text { Occupation }}}{\frac{\text { Indicators }}{\text { col. } 2}}$ & $\begin{array}{c}\frac{\text { Equity }}{\text { Premium }} \\
\frac{\text { Knowledge }}{\text { col. } 3}\end{array}$ \\
\hline Female & $\%$ & 53.9 & 53.7 & 52.9 \\
\hline Age & $\begin{array}{l}\text { mean } \\
\text { (sd) }\end{array}$ & $\begin{array}{c}64.53 \\
{[10.12]}\end{array}$ & $\begin{array}{c}64.37 \\
{[10.08]}\end{array}$ & $\begin{array}{c}64.14 \\
{[9.794]}\end{array}$ \\
\hline Education (years) & $\begin{array}{l}\text { mean } \\
(\mathrm{sd})\end{array}$ & $\begin{array}{c}14.38 \\
{[2.292]}\end{array}$ & $\begin{array}{c}14.39 \\
{[2.286]}\end{array}$ & $\begin{array}{c}14.6 \\
{[2.180]}\end{array}$ \\
\hline Number Economics Courses & $\begin{array}{l}\text { mean } \\
(\mathrm{sd})\end{array}$ & $\begin{array}{c}1.302 \\
{[2.293]}\end{array}$ & $\begin{array}{c}1.312 \\
{[2.312]}\end{array}$ & $\begin{array}{c}1.383 \\
{[2.343]}\end{array}$ \\
\hline Number Series Score & $\begin{array}{l}\text { mean } \\
\text { (sd) }\end{array}$ & $\begin{array}{c}524.5 \\
{[27.79]}\end{array}$ & $\begin{array}{c}524.7 \\
{[27.62]}\end{array}$ & $\begin{array}{c}526.7 \\
{[27.67]}\end{array}$ \\
\hline $\begin{array}{l}\text { Financial Knowledge } \\
\text { Measures } \\
\text { Attitudinal Financial } \\
\text { Knowledge }\end{array}$ & $\begin{array}{l}\text { mean } \\
\text { (sd) }\end{array}$ & $\begin{array}{c}0.0268 \\
{[0.984]}\end{array}$ & & \\
\hline Factual Financial Knowledge & $\begin{array}{l}\text { mean } \\
(\mathrm{sd})\end{array}$ & $\begin{array}{c}0.023 \\
{[0.988]}\end{array}$ & & \\
\hline Equity Premium Knowledge & $\begin{array}{l}\text { mean } \\
(\mathrm{sd})\end{array}$ & & & $\begin{array}{c}0.67 \\
{[0.471]}\end{array}$ \\
\hline $\begin{array}{l}\text { Financial Occupation } \\
\text { Measures }\end{array}$ & & & & \\
\hline Financial Occupation: Budget & $\begin{array}{l}\text { mean } \\
\text { (sd) }\end{array}$ & & $\begin{array}{c}0.224 \\
{[0.417]}\end{array}$ & \\
\hline Financial Occupation: Math & $\begin{array}{l}\text { mean } \\
\text { (sd) }\end{array}$ & & $\begin{array}{c}0.109 \\
{[0.312]}\end{array}$ & \\
\hline $\begin{array}{l}\text { Financial Occupation: } \\
\text { Finance }\end{array}$ & $\begin{array}{l}\text { mean } \\
\text { (sd) }\end{array}$ & & $\begin{array}{l}0.0667 \\
{[0.250]}\end{array}$ & \\
\hline $\begin{array}{l}\text { Financial Occupation } \\
\text { Indicator }\end{array}$ & $\begin{array}{l}\text { mean } \\
\text { (sd) }\end{array}$ & & $\begin{array}{c}0.276 \\
{[0.447]}\end{array}$ & \\
\hline $\begin{array}{l}\text { Lower Bar } \\
\text { Financial Occ. } \\
\text { Indicator }\end{array}$ & $\begin{array}{l}\text { mean } \\
(\mathrm{sd})\end{array}$ & & $\begin{array}{c}0.549 \\
{[0.498]}\end{array}$ & \\
\hline Observations & & 903 & 869 & 669 \\
\hline
\end{tabular}


Figure 1: Three financial occupation variables

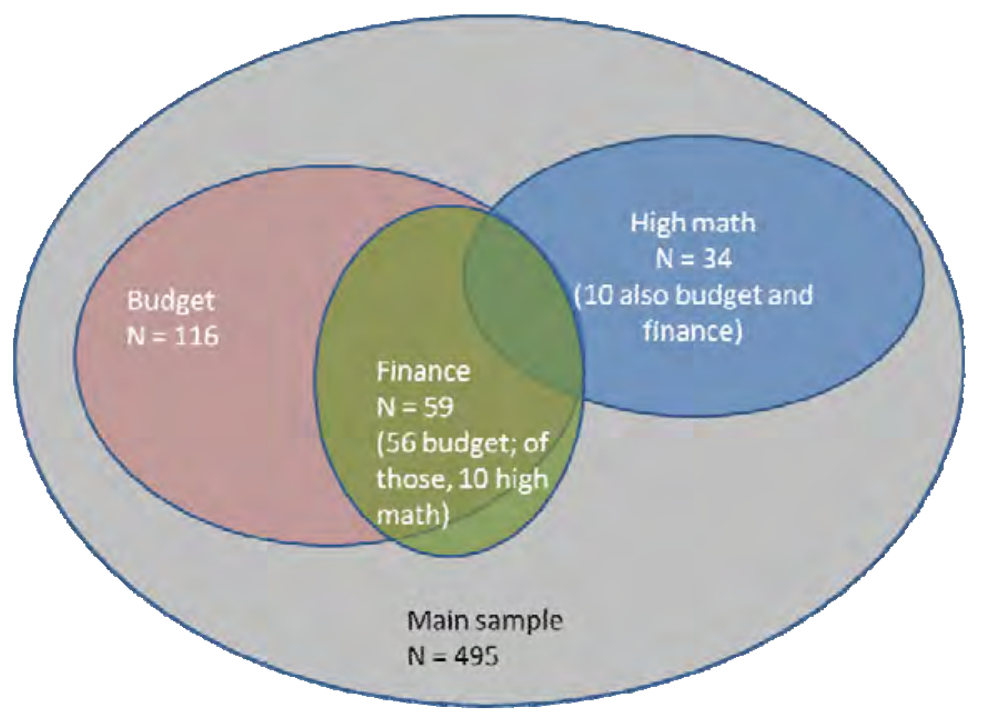

Figure 2: Relationship between financial occupation indicator and lower-bar indicator

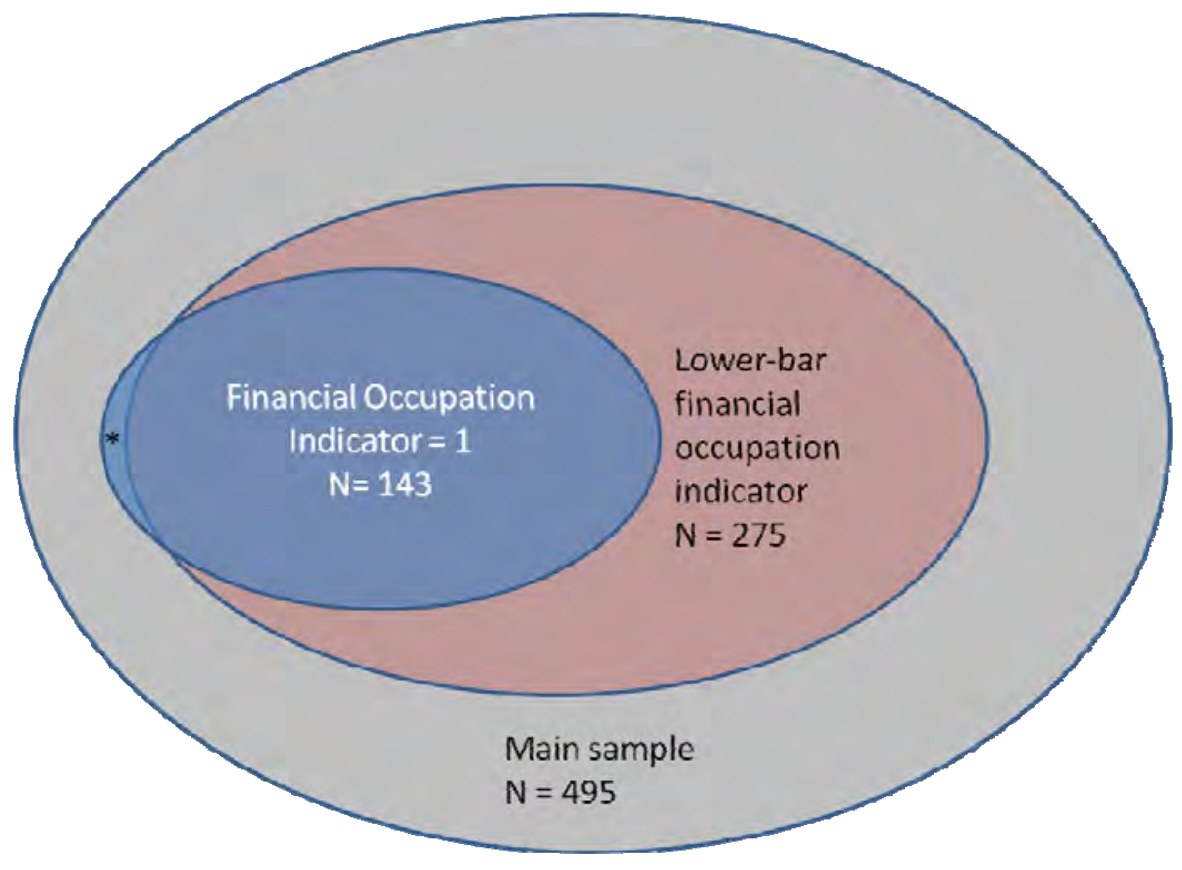

* 2 computer programmers and 1 chef 
Table 2: Relationship between occupation and financial knowledge

\begin{tabular}{lcccc} 
& & $\begin{array}{c}\text { "Attitudinal" } \\
\text { Financial } \\
\text { Knowledge }\end{array}$ & $\begin{array}{c}\text { "Factual" } \\
\text { Financial } \\
\text { Knowledge }\end{array}$ & $\begin{array}{c}\text { Equity } \\
\text { Premium } \\
\text { Awareness }\end{array}$ \\
\hline Occupation Indicator & Yes & 0.32 & Mean & $\%$ Correct \\
\hline Budget? & No & -0.04 & -36 & $81.6 \%$ \\
\hline High math content? & Yes & 0.50 & 0.68 & $64.9 \%$ \\
\hline High financial content? & No & 0.01 & 0.01 & $67.2 \%$ \\
& Yes & 0.45 & 0.53 & $92.3 \%$ \\
\hline Composite indicator of above & No & -0.01 & -0.01 & $65.5 \%$ \\
\hline 3? & Yes & 0.33 & 0.40 & $83.2 \%$ \\
\hline Lower-bar financial occ.? & No & -0.07 & -0.08 & $62.9 \%$ \\
\hline
\end{tabular}

Note: Rows give the means of the financial knowledge indicator for a particular group. For example, the first row gives the means of the three financial knowledge measures for individuals whose occupations were given a " 1 " for the "budget" indicator variable, while the second row gives the means for those who did not receive a " 1 " for the "budget” variable.

Table 3: Pairwise correlations between variables

\begin{tabular}{|c|c|c|c|c|c|c|}
\hline & $\begin{array}{c}\text { "Factual" } \\
\text { Financial } \\
\text { Knowledge }\end{array}$ & $\begin{array}{l}\text { "Attitudinal" } \\
\text { Financial } \\
\text { Knowledge }\end{array}$ & $\begin{array}{c}\text { Equity } \\
\text { Premium } \\
\text { Awareness }\end{array}$ & $\begin{array}{l}\text { Years of } \\
\text { Education }\end{array}$ & $\begin{array}{c}\text { Number } \\
\text { Economics } \\
\text { Courses }\end{array}$ & $\begin{array}{c}\text { Number } \\
\text { Series } \\
\text { Score }\end{array}$ \\
\hline $\begin{array}{l}\text { "Factual" Fin. Knowledge } \\
\text { "Attitudinal" Fin. }\end{array}$ & 1 & & & & & \\
\hline Knowledge & 0.7938 & 1 & & & & \\
\hline Equity Premium Awareness & 0.3495 & 0.3252 & 1 & & & \\
\hline Education (yrs) & 0.3097 & 0.3338 & 0.2412 & 1 & & \\
\hline Number Economics Courses & 0.1842 & 0.2262 & 0.2046 & 0.321 & 1 & \\
\hline Number Series Score & 0.2679 & 0.3075 & 0.18 & 0.3625 & 0.1537 & 1 \\
\hline
\end{tabular}


Table 4: Linear regressions: financial knowledge on exogenous and education variables

(1)

\section{Attitudinal \\ Financial \\ Knowledge, \\ Standardized}

\begin{tabular}{|c|c|c|c|}
\hline & $\begin{array}{c}\text { Attitudinal } \\
\text { Financial } \\
\text { Knowledge, } \\
\text { Standardized }\end{array}$ & $\begin{array}{c}\text { Factual Financial } \\
\text { Knowledge, } \\
\text { Standardized } \\
\end{array}$ & $\begin{array}{c}\text { Equity Premium } \\
\text { Knowledge } \\
(0 / 1 \text { indicator })\end{array}$ \\
\hline \multirow[t]{2}{*}{ Age } & $-0.0174 * * *$ & $-0.0125 * * *$ & 0.000802 \\
\hline & {$[0.00511]$} & {$[0.00454]$} & {$[0.00251]$} \\
\hline \multirow[t]{2}{*}{ Education (years) } & $0.0863^{* * *}$ & $0.0664 * * *$ & $0.0380 * * *$ \\
\hline & {$[0.0156]$} & {$[0.0160]$} & {$[0.00929]$} \\
\hline \multirow[t]{2}{*}{ Number economics courses } & 0.0118 & $0.0335 * *$ & $0.0264 * * *$ \\
\hline & {$[0.0170]$} & {$[0.0158]$} & {$[0.00863]$} \\
\hline \multirow[t]{2}{*}{ Number Series } & $0.157 * * *$ & $0.251 * * *$ & $0.0640 * *$ \\
\hline & {$[0.0590]$} & {$[0.0592]$} & {$[0.0252]$} \\
\hline \multirow[t]{2}{*}{ Sex } & $-0.186 * *$ & $-0.363 * * *$ & $-0.153 * * *$ \\
\hline & {$[0.0934]$} & {$[0.0842]$} & {$[0.0505]$} \\
\hline \multirow[t]{2}{*}{ Constant } & $-2.827 * * *$ & $-4.397 * * *$ & $-1.042 * *$ \\
\hline & [0.987] & [1.071] & {$[0.518]$} \\
\hline Observations & 903 & 903 & 669 \\
\hline R-squared & 0.147 & 0.198 & 0.132 \\
\hline
\end{tabular}

Robust standard errors in brackets. *** $\mathrm{p}<0.01, * * \mathrm{p}<0.05,{ }^{*} \mathrm{p}<0.1$

(3)

(2) 
Table 5: Linear regressions: Financial Occupation Indicators on exogenous and education variables

\begin{tabular}{|c|c|c|c|c|c|}
\hline & $\begin{array}{c}(1) \\
\text { Financial } \\
\text { Occupation: } \\
\text { Budget } \\
(\mathbf{0} / \mathbf{1} \\
\text { indicator) } \\
\end{array}$ & $\begin{array}{c}(2) \\
\text { Financial } \\
\text { Occupation: } \\
\text { Finance } \\
(\mathbf{0} / \mathbf{1} \\
\text { indicator }) \\
\end{array}$ & $\begin{array}{c}(3) \\
\text { Financial } \\
\text { Occupation: } \\
\text { Math } \\
\text { (0/1 } \\
\text { indicator) } \\
\end{array}$ & $\begin{array}{c}(4) \\
\text { Financial } \\
\text { Occupation } \\
(0 / 1 \\
\text { indicator })\end{array}$ & $\begin{array}{c}(5) \\
\text { Lower Bar } \\
\text { Financial } \\
\text { Occupation } \\
\text { (0/1 } \\
\text { indicator) }\end{array}$ \\
\hline Age & $\begin{array}{c}0.00263 \\
{[0.00165]}\end{array}$ & $\begin{array}{c}0.000249 \\
{[0.000817]}\end{array}$ & $\begin{array}{c}-6.04 \mathrm{E}-05 \\
{[0.000688]}\end{array}$ & $\begin{array}{c}0.00237 \\
{[0.00165]}\end{array}$ & $\begin{array}{l}0.0121^{* * *} \\
{[0.00199]}\end{array}$ \\
\hline Education (years) & $\begin{array}{c}0.0135 * \\
{[0.00713]}\end{array}$ & $\begin{array}{l}0.00716^{*} \\
{[0.00374]}\end{array}$ & $\begin{array}{l}0.00669 * * \\
{[0.00302]}\end{array}$ & $\begin{array}{l}0.0197 * * * \\
{[0.00740]}\end{array}$ & $\begin{array}{c}0.0355^{* * *} \\
{[0.00779]}\end{array}$ \\
\hline $\begin{array}{l}\text { Number economics } \\
\text { courses }\end{array}$ & $\begin{array}{c}0.0537 * * * \\
{[0.00822]}\end{array}$ & $\begin{array}{l}0.0468 * * * \\
{[0.00810]}\end{array}$ & $\begin{array}{l}0.0117 * * \\
{[0.00522]}\end{array}$ & $\begin{array}{l}0.0540 * * * \\
{[0.00811]}\end{array}$ & $\begin{array}{l}0.0398 * * * \\
{[0.00739]}\end{array}$ \\
\hline Number Series & $\begin{array}{c}0.0248 \\
{[0.0271]}\end{array}$ & $\begin{array}{l}0.00669 \\
{[0.0183]}\end{array}$ & $\begin{array}{c}0.0116 \\
{[0.00897]}\end{array}$ & $\begin{array}{c}0.0358 \\
{[0.0265]}\end{array}$ & $\begin{array}{c}0.0289 \\
{[0.0266]}\end{array}$ \\
\hline Sex & $\begin{array}{c}-0.0355 \\
{[0.0314]}\end{array}$ & $\begin{array}{l}0.00673 \\
{[0.0198]}\end{array}$ & $\begin{array}{c}-0.0497 * * * \\
{[0.0152]}\end{array}$ & $\begin{array}{c}-0.0890 * * * \\
{[0.0330]}\end{array}$ & $\begin{array}{c}0.023 \\
{[0.0435]}\end{array}$ \\
\hline Constant & $\begin{array}{c}-0.632 \\
{[0.488]}\end{array}$ & $\begin{array}{c}-0.193 \\
{[0.321]}\end{array}$ & $\begin{array}{c}-0.223 \\
{[0.161]}\end{array}$ & $\begin{array}{l}-0.821^{*} \\
{[0.480]}\end{array}$ & $\begin{array}{c}-1.311^{* * *} \\
{[0.486]}\end{array}$ \\
\hline Observations & 876 & 876 & 876 & 876 & 869 \\
\hline R-squared & 0.12 & 0.136 & 0.05 & 0.144 & 0.125 \\
\hline
\end{tabular}

Robust standard errors in brackets. *** $\mathrm{p}<0.01$, ** $\mathrm{p}<0.05$, $* \mathrm{p}<0.1$ 
Table 6: Regressions: Attitudinal Financial Knowledge and Occupation

\begin{tabular}{|c|c|c|c|c|c|c|}
\hline & (1) & (2) & (3) & (4) & (5) & (6) \\
\hline Dependent Variable: & \multicolumn{6}{|c|}{ Attitudinal Financial Knowledge, Standardized } \\
\hline \multicolumn{7}{|c|}{ Financial Occupation (=1 for $\mathrm{HH}$ if either individual =1): } \\
\hline Budget & & $\begin{array}{c}0.251^{*} \\
{[0.144]}\end{array}$ & & & & \\
\hline Math & & & $\begin{array}{c}0.183 \\
{[0.138]}\end{array}$ & & & \\
\hline Finance & & & & $\begin{array}{c}0.356^{*} \\
{[0.210]}\end{array}$ & & \\
\hline Composite Indicator & & & & & $\begin{array}{c}0.270 * \\
{[0.139]}\end{array}$ & \\
\hline Lower Bar Indicator & & & & & & $\begin{array}{l}0.0789 \\
{[0.159]}\end{array}$ \\
\hline $\begin{array}{l}\text { In(Lifetime HH } \\
\text { earnings) }\end{array}$ & $\begin{array}{c}0.535^{* * *} \\
{[0.162]}\end{array}$ & $\begin{array}{c}0.494 * * * \\
{[0.170]}\end{array}$ & $\begin{array}{c}0.522^{* * *} \\
{[0.163]}\end{array}$ & $\begin{array}{c}0.518 * * * \\
{[0.167]}\end{array}$ & $\begin{array}{c}0.479 * * * \\
{[0.173]}\end{array}$ & $\begin{array}{c}0.519 * * * \\
{[0.162]}\end{array}$ \\
\hline Number Series Score & $\begin{array}{c}0.15 \\
{[0.0984]}\end{array}$ & $\begin{array}{c}0.144 \\
{[0.0981]}\end{array}$ & $\begin{array}{c}0.147 \\
{[0.0980]}\end{array}$ & $\begin{array}{c}0.142 \\
{[0.0971]}\end{array}$ & $\begin{array}{c}0.139 \\
{[0.0974]}\end{array}$ & $\begin{array}{c}0.146 \\
{[0.102]}\end{array}$ \\
\hline $\begin{array}{l}\text { \# Econ Courses (HH } \\
\text { max) }\end{array}$ & $\begin{array}{c}0.0235 \\
{[0.0196]}\end{array}$ & $\begin{array}{c}0.0117 \\
{[0.0226]}\end{array}$ & $\begin{array}{c}0.0218 \\
{[0.0197]}\end{array}$ & $\begin{array}{l}0.00485 \\
{[0.0256]}\end{array}$ & $\begin{array}{c}0.0125 \\
{[0.0219]}\end{array}$ & $\begin{array}{c}0.022 \\
{[0.0203]}\end{array}$ \\
\hline Age (max in HH) & $\begin{array}{c}-0.0203^{* * *} \\
{[0.00742]}\end{array}$ & $\begin{array}{c}-0.0209 * * * \\
{[0.00746]}\end{array}$ & $\begin{array}{c}-0.0205^{* * *} \\
{[0.00743]}\end{array}$ & $\begin{array}{c}-0.0204 * * * \\
{[0.00738]}\end{array}$ & $\begin{array}{c}-0.0211^{* * *} \\
{[0.00748]}\end{array}$ & $\begin{array}{c}-0.0212^{* * *} \\
{[0.00717]}\end{array}$ \\
\hline Male education & $\begin{array}{c}0.0524^{* *} \\
{[0.0236]}\end{array}$ & $\begin{array}{c}0.0502 * * \\
{[0.0235]}\end{array}$ & $\begin{array}{c}0.0509 * * \\
{[0.0235]}\end{array}$ & $\begin{array}{c}0.0528^{* *} \\
{[0.0236]}\end{array}$ & $\begin{array}{c}0.0476^{* *} \\
{[0.0233]}\end{array}$ & $\begin{array}{l}0.0512^{* *} \\
{[0.0247]}\end{array}$ \\
\hline Female education & $\begin{array}{c}0.0641 * * * \\
{[0.0210]}\end{array}$ & $\begin{array}{c}0.0634 * * * \\
{[0.0213]}\end{array}$ & $\begin{array}{c}0.0629 * * * \\
{[0.0209]}\end{array}$ & $\begin{array}{c}0.0641^{* * *} \\
{[0.0208]}\end{array}$ & $\begin{array}{c}0.0611^{* * *} \\
{[0.0212]}\end{array}$ & $\begin{array}{c}0.0623 * * * \\
{[0.0224]}\end{array}$ \\
\hline Single indicator & $\begin{array}{c}1.100 * * \\
{[0.428]}\end{array}$ & $\begin{array}{c}1.052 * * \\
{[0.420]}\end{array}$ & $\begin{array}{c}1.082 * * \\
{[0.426]}\end{array}$ & $\begin{array}{c}1.112 * * * \\
{[0.422]}\end{array}$ & $\begin{array}{c}1.023 * * \\
{[0.418]}\end{array}$ & $\begin{array}{c}1.083 * * \\
{[0.445]}\end{array}$ \\
\hline Constant & $\begin{array}{c}-8.178^{* * *} \\
{[2.342]} \\
\end{array}$ & $\begin{array}{c}-7.562^{* * *} \\
{[2.449]} \\
\end{array}$ & $\begin{array}{c}-7.949 * * * \\
{[2.366]} \\
\end{array}$ & $\begin{array}{c}-7.961 * * * \\
{[2.412]} \\
\end{array}$ & $\begin{array}{c}-7.288 * * * \\
{[2.496]} \\
\end{array}$ & $\begin{array}{c}-7.906 * * * \\
{[2.392]} \\
\end{array}$ \\
\hline Observations & 494 & 494 & 494 & 494 & 494 & 494 \\
\hline R-squared & 0.21 & 0.218 & 0.211 & 0.218 & 0.22 & 0.211 \\
\hline
\end{tabular}

Robust standard errors in brackets. ${ }^{* * *} \mathrm{p}<0.01,{ }^{* *} \mathrm{p}<0.05,{ }^{*} \mathrm{p}<0.1$.

+ denotes imputed variable 
Table 7: Regressions: Factual Financial Knowledge and Occupation

\begin{tabular}{|c|c|c|c|c|c|c|}
\hline & (1) & $(2)$ & (3) & $(4)$ & $(5)$ & (6) \\
\hline Dependent Variable: & \multicolumn{6}{|c|}{ “Factual” Financial Knowledge, Standardized } \\
\hline \multicolumn{7}{|c|}{ Financial Occupation (=1 for HH if either individual =1): } \\
\hline Budget & & $\begin{array}{c}0.184 \\
{[0.116]}\end{array}$ & & & & \\
\hline Math & & & $\begin{array}{l}0.213^{*} \\
{[0.129]}\end{array}$ & & & \\
\hline Finance & & & & $\begin{array}{c}0.177 \\
{[0.168]}\end{array}$ & & \\
\hline Composite Indicator & & & & & $\begin{array}{l}0.221 * * \\
{[0.107]}\end{array}$ & \\
\hline Lower Bar Indicator & & & & & & $\begin{array}{c}0.107 \\
{[0.128]}\end{array}$ \\
\hline $\begin{array}{l}\ln (\text { Lifetime HH } \\
\text { earnings) }\end{array}$ & $\begin{array}{c}0.335 * * \\
{[0.141]}\end{array}$ & $\begin{array}{c}0.305 * * \\
{[0.136]}\end{array}$ & $\begin{array}{l}0.320 * * \\
{[0.144]}\end{array}$ & $\begin{array}{l}0.327 * * \\
{[0.138]}\end{array}$ & $\begin{array}{c}0.289 * * \\
{[0.137]}\end{array}$ & $\begin{array}{c}0.314^{* *} \\
{[0.139]}\end{array}$ \\
\hline Number Series Score & $\begin{array}{l}0.237 * * * \\
{[0.0871]}\end{array}$ & $\begin{array}{l}0.232 * * * \\
{[0.0850]}\end{array}$ & $\begin{array}{c}0.233 * * * \\
{[0.0875]}\end{array}$ & $\begin{array}{l}0.233^{* * *} \\
{[0.0874]}\end{array}$ & $\begin{array}{l}0.228 * * * \\
{[0.0845]}\end{array}$ & $\begin{array}{l}0.231^{* * *} \\
{[0.0882]}\end{array}$ \\
\hline $\begin{array}{l}\text { \# Econ Courses (HH } \\
\text { max) }\end{array}$ & $\begin{array}{c}0.0571 * * * \\
{[0.0194]}\end{array}$ & $\begin{array}{l}0.0485 * * \\
{[0.0204]}\end{array}$ & $\begin{array}{c}0.0552 * * * \\
{[0.0196]}\end{array}$ & $\begin{array}{l}0.0479 * * \\
{[0.0219]}\end{array}$ & $\begin{array}{c}0.0482 * * \\
{[0.0198]}\end{array}$ & $\begin{array}{c}0.0551^{* * *} \\
{[0.0195]}\end{array}$ \\
\hline Age (max in $\mathbf{H H})$ & $\begin{array}{l}-0.0112^{*} \\
{[0.00657]}\end{array}$ & $\begin{array}{l}-0.0116^{*} \\
{[0.00657]}\end{array}$ & $\begin{array}{l}-0.0115^{*} \\
{[0.00660]}\end{array}$ & $\begin{array}{l}-0.0113^{*} \\
{[0.00656]}\end{array}$ & $\begin{array}{c}-0.0118^{*} \\
{[0.00660]}\end{array}$ & $\begin{array}{l}-0.0124 * * \\
{[0.00632]}\end{array}$ \\
\hline Male education & $\begin{array}{c}0.0541 * * * \\
{[0.0206]}\end{array}$ & $\begin{array}{c}0.0525 * * \\
{[0.0205]}\end{array}$ & $\begin{array}{l}0.0523 * * \\
{[0.0206]}\end{array}$ & $\begin{array}{c}0.0543 * * * \\
{[0.0206]}\end{array}$ & $\begin{array}{l}0.0501 * * \\
{[0.0203]}\end{array}$ & $\begin{array}{c}0.0525 * * \\
{[0.0212]}\end{array}$ \\
\hline Female education & $\begin{array}{l}0.0344^{*} \\
{[0.0206]}\end{array}$ & $\begin{array}{l}0.0338 * \\
{[0.0205]}\end{array}$ & $\begin{array}{c}0.033 \\
{[0.0205]}\end{array}$ & $\begin{array}{c}0.0344^{*} \\
{[0.0206]}\end{array}$ & $\begin{array}{c}0.0319 \\
{[0.0202]}\end{array}$ & $\begin{array}{c}0.0319 \\
{[0.0210]}\end{array}$ \\
\hline Single indicator & $\begin{array}{c}0.799 * * \\
{[0.353]}\end{array}$ & $\begin{array}{c}0.763 * * \\
{[0.348]}\end{array}$ & $\begin{array}{c}0.778 * * \\
{[0.351]}\end{array}$ & $\begin{array}{c}0.805 * * \\
{[0.352]}\end{array}$ & $\begin{array}{c}0.735 * * \\
{[0.346]}\end{array}$ & $\begin{array}{c}0.775^{* *} \\
{[0.362]}\end{array}$ \\
\hline Constant & $\begin{array}{c}-5.404 * * \\
{[2.128]}\end{array}$ & $\begin{array}{c}-4.951 * * \\
{[2.063]}\end{array}$ & $\begin{array}{c}-5.138 * * \\
{[2.165]}\end{array}$ & $\begin{array}{c}-5.297 * * \\
{[2.090]}\end{array}$ & $\begin{array}{c}-4.677^{* *} \\
{[2.080]}\end{array}$ & $\begin{array}{c}-5.036 * * \\
{[2.109]}\end{array}$ \\
\hline Observations & 494 & 494 & 494 & 494 & 494 & 494 \\
\hline R-squared & 0.241 & 0.246 & 0.244 & 0.244 & 0.249 & 0.244 \\
\hline
\end{tabular}

Robust standard errors in brackets. ${ }^{* * *} \mathrm{p}<0.01,{ }^{* *} \mathrm{p}<0.05$, * $\mathrm{p}<0.1$.

+ denotes imputed variable 
Table 8: Regressions: Equity Premium Knowledge and Occupation

\begin{tabular}{|c|c|c|c|c|c|c|}
\hline & (1) & (2) & (3) & (4) & (5) & (6) \\
\hline Dependent Variable: & \multicolumn{6}{|c|}{ Equity Premium Knowledge } \\
\hline \multicolumn{7}{|c|}{ Financial Occupation (=1 for HH if either individual =1): } \\
\hline Budget & & $\begin{array}{c}0.0597 \\
{[0.0665]}\end{array}$ & & & & \\
\hline Math & & & $\begin{array}{l}0.121 * * \\
{[0.0554]}\end{array}$ & & & \\
\hline Finance & & & & $\begin{array}{c}0.0768 \\
{[0.0927]}\end{array}$ & & \\
\hline Composite Indicator & & & & & $\begin{array}{c}0.0945 \\
{[0.0644]}\end{array}$ & \\
\hline Lower Bar Indicator & & & & & & $\begin{array}{c}0.077 \\
{[0.0697]}\end{array}$ \\
\hline $\begin{array}{l}\text { In(Lifetime HH } \\
\text { earnings) }\end{array}$ & $0.307 * * *$ & $0.299 * * *$ & $0.293^{* * *}$ & $0.302 * * *$ & $0.287 * * *$ & $0.291^{* * *}$ \\
\hline & $\begin{array}{c}{[0.0695]} \\
0.0834^{* *} \\
*\end{array}$ & $\begin{array}{c}{[0.0695]} \\
0.0831^{* *} \\
*\end{array}$ & $\begin{array}{c}{[0.0709]} \\
0.0807 * * \\
*\end{array}$ & $\begin{array}{c}{[0.0677]} \\
0.0807 * * \\
*\end{array}$ & $\begin{array}{c}{[0.0700]} \\
0.0815^{* *} \\
*\end{array}$ & $\begin{array}{c}{[0.0701]} \\
0.0816^{* *} \\
*\end{array}$ \\
\hline Number Series Score & $\begin{array}{c}* \\
{[0.0295]}\end{array}$ & $\begin{array}{c}* \\
{[0.0294]}\end{array}$ & $\begin{array}{c}* \\
{[0.0294]}\end{array}$ & [0.0298] & [0.0292] & [0.0288] \\
\hline $\begin{array}{l}\text { \# Econ Courses (HH } \\
\text { max) }\end{array}$ & $\begin{array}{l}0.0195^{* *} \\
{[0.00914]}\end{array}$ & $\begin{array}{c}0.0165^{*} \\
{[0.00961]}\end{array}$ & $\begin{array}{l}0.0187 * * \\
{[0.00919]}\end{array}$ & $\begin{array}{c}0.015 \\
{[0.0110]}\end{array}$ & $\begin{array}{c}0.0155^{*} \\
{[0.00920]}\end{array}$ & $\begin{array}{c}0.0175^{*} \\
{[0.00901]}\end{array}$ \\
\hline Age (max in $\mathbf{H H})$ & $\begin{array}{c}0.00374 \\
{[0.00320]}\end{array}$ & $\begin{array}{c}0.00365 \\
{[0.00322]}\end{array}$ & $\begin{array}{c}0.00362 \\
{[0.00320]}\end{array}$ & $\begin{array}{c}0.00372 \\
{[0.00323]}\end{array}$ & $\begin{array}{c}0.0036 \\
{[0.00323]}\end{array}$ & $\begin{array}{c}0.00288 \\
{[0.00325]}\end{array}$ \\
\hline Male education & $\begin{array}{c}0.0256^{* *} \\
{[0.0105]}\end{array}$ & $\begin{array}{c}0.0249 * * \\
{[0.0105]}\end{array}$ & $\begin{array}{c}0.0246 * * \\
{[0.0104]}\end{array}$ & $\begin{array}{c}0.0260 * * \\
{[0.0105]}\end{array}$ & $\begin{array}{l}0.0237 * * \\
{[0.0105]}\end{array}$ & $\begin{array}{c}0.0240 * * \\
{[0.0107]}\end{array}$ \\
\hline Female education & $\begin{array}{c}0.0331 * * \\
* \\
{[0.00980]}\end{array}$ & $\begin{array}{c}0.0326 * * \\
* \\
{[0.00977]}\end{array}$ & $\begin{array}{c}0.0323 * * \\
* \\
{[0.00974]}\end{array}$ & $\begin{array}{c}0.0336 * * \\
* \\
{[0.00982]}\end{array}$ & $\begin{array}{c}0.0315^{* *} \\
* \\
{[0.00973]}\end{array}$ & $\begin{array}{c}0.0306 * * \\
* \\
{[0.0101]}\end{array}$ \\
\hline Single indicator & $\begin{array}{c}0.501^{* * * *} \\
{[0.157]}\end{array}$ & $\begin{array}{c}0.493 * * * \\
{[0.156]}\end{array}$ & $\begin{array}{c}0.483^{* * *} \\
{[0.156]}\end{array}$ & $\begin{array}{c}0.508 * * * \\
{[0.157]}\end{array}$ & $\begin{array}{c}0.475^{* * *} \\
{[0.155]}\end{array}$ & $\begin{array}{c}0.478 * * * \\
{[0.163]}\end{array}$ \\
\hline Constant & $\begin{array}{c}-4.892 * * * \\
{[0.999]} \\
\end{array}$ & $\begin{array}{c}-4.777 * * * \\
{[1.000]} \\
\end{array}$ & $\begin{array}{c}-4.676^{* * *} \\
{[1.013]} \\
\end{array}$ & $\begin{array}{c}-4.845^{* * *} \\
{[0.974]} \\
\end{array}$ & $\begin{array}{c}-4.583 * * * \\
{[1.010]} \\
\end{array}$ & $\begin{array}{c}-4.606 * * * \\
{[1.025]} \\
\end{array}$ \\
\hline Observations & 377 & 377 & 377 & 377 & 377 & 377 \\
\hline R-squared & 0.221 & 0.224 & 0.226 & 0.224 & 0.228 & 0.226 \\
\hline
\end{tabular}

Robust standard errors in brackets. ${ }^{* * *} \mathrm{p}<0.01,{ }^{* *} \mathrm{p}<0.05{ }^{*} \mathrm{p}<0.1$.

+ denotes imputed variable 
Table 9: Regressions: Retirement Wealth and Occupation

\begin{tabular}{|c|c|c|c|c|c|c|}
\hline & (1) & (2) & (3) & (4) & (5) & (6) \\
\hline Dependent Variable: & \multicolumn{6}{|c|}{ In (Retirement Wealth) } \\
\hline \multicolumn{7}{|c|}{ Financial Occupation (=1 for $\mathrm{HH}$ if either individual =1): } \\
\hline Budget & & $\begin{array}{c}0.425 \\
{[0.679]}\end{array}$ & & & & \\
\hline Math & & & $\begin{array}{c}0.464 \\
{[0.689]}\end{array}$ & & & \\
\hline Finance & & & & $\begin{array}{c}1.125 \\
{[0.848]}\end{array}$ & & \\
\hline Composite Indicator & & & & & $\begin{array}{c}0.619 \\
{[0.644]}\end{array}$ & \\
\hline Lower Bar Indicator & & & & & & $\begin{array}{c}0.652 \\
{[0.655]}\end{array}$ \\
\hline $\begin{array}{l}\text { ln(Lifetime HH } \\
\text { earnings) }\end{array}$ & $\begin{array}{c}2.996 * * * \\
{[0.769]}\end{array}$ & $\begin{array}{c}2.927 * * * \\
{[0.775]}\end{array}$ & $\begin{array}{c}2.962 * * * \\
{[0.778]}\end{array}$ & $\begin{array}{c}2.943^{* * *} \\
{[0.759]}\end{array}$ & $\begin{array}{c}2.867 * * * \\
{[0.782]}\end{array}$ & $\begin{array}{c}2.870 * * * \\
{[0.774]}\end{array}$ \\
\hline Number Series Score & $\begin{array}{c}1.114 * * * \\
{[0.366]}\end{array}$ & $\begin{array}{c}1.103 * * * \\
{[0.362]}\end{array}$ & $\begin{array}{c}1.106^{* * *} \\
{[0.368]}\end{array}$ & $\begin{array}{c}1.089 * * * \\
{[0.369]}\end{array}$ & $\begin{array}{c}1.088 * * * \\
{[0.361]}\end{array}$ & $\begin{array}{c}1.079 * * * \\
{[0.361]}\end{array}$ \\
\hline $\begin{array}{l}\text { \# Econ Courses (HH } \\
\text { max) }\end{array}$ & $\begin{array}{c}0.144 \\
{[0.107]}\end{array}$ & $\begin{array}{c}0.124 \\
{[0.114]}\end{array}$ & $\begin{array}{c}0.14 \\
{[0.107]} \\
-\end{array}$ & $\begin{array}{c}0.0854 \\
{[0.124]} \\
-\end{array}$ & $\begin{array}{c}0.119 \\
{[0.110]}\end{array}$ & $\begin{array}{c}0.132 \\
{[0.106]} \\
-\end{array}$ \\
\hline Age (max in HH) & $\begin{array}{c}0.0981 * * * \\
{[0.0333]}\end{array}$ & $\begin{array}{c}0.0990 * * * \\
{[0.0334]}\end{array}$ & $\begin{array}{c}0.0987 * * * \\
{[0.0334]}\end{array}$ & $\begin{array}{c}0.0985 * * * \\
{[0.0334]}\end{array}$ & $\begin{array}{c}0.0997 * * * \\
{[0.0334]}\end{array}$ & $\begin{array}{c}0.106 * * * \\
{[0.0322]}\end{array}$ \\
\hline Male education & $\begin{array}{c}0.217^{*} \\
{[0.116]}\end{array}$ & $\begin{array}{c}0.213^{*} \\
{[0.115]}\end{array}$ & $\begin{array}{c}0.213^{*} \\
{[0.116]}\end{array}$ & $\begin{array}{c}0.218 * \\
{[0.115]}\end{array}$ & $\begin{array}{c}0.206^{*} \\
{[0.115]}\end{array}$ & $\begin{array}{c}0.207 * \\
{[0.115]}\end{array}$ \\
\hline Female education & $\begin{array}{c}0.201 * * \\
{[0.0991]}\end{array}$ & $\begin{array}{l}0.200 * * \\
{[0.0978]}\end{array}$ & $\begin{array}{c}0.198 * * \\
{[0.0991]}\end{array}$ & $\begin{array}{l}0.201 * * \\
{[0.0989]}\end{array}$ & $\begin{array}{c}0.194 * * \\
{[0.0972]}\end{array}$ & $\begin{array}{c}0.186^{*} \\
{[0.0982]}\end{array}$ \\
\hline Single indicator & $\begin{array}{c}4.634^{* * *} \\
{[1.700]}\end{array}$ & $\begin{array}{c}4.550 * * * \\
{[1.683]}\end{array}$ & $\begin{array}{c}4.588 * * * \\
{[1.700]}\end{array}$ & $\begin{array}{c}4.669 * * * \\
{[1.688]}\end{array}$ & $\begin{array}{c}4.452^{* * *} \\
{[1.679]}\end{array}$ & $\begin{array}{c}4.501^{* * *} \\
{[1.687]} \\
-\end{array}$ \\
\hline Constant & $\begin{array}{c}-35.10 * * * \\
{[11.09]} \\
\end{array}$ & $\begin{array}{c}-34.05^{* * *} \\
{[11.14]} \\
\end{array}$ & $\begin{array}{c}-34.52 * * * \\
{[11.21]} \\
\end{array}$ & $\begin{array}{c}-34.41 * * * \\
{[10.94]} \\
\end{array}$ & $\begin{array}{c}-33.04 * * * \\
{[11.25]} \\
\end{array}$ & $\begin{array}{c}32.89 * * * \\
{[11.15]}\end{array}$ \\
\hline Observations & 495 & 495 & 495 & 495 & 495 & 495 \\
\hline R-squared & 0.249 & 0.25 & 0.249 & 0.252 & 0.251 & 0.251 \\
\hline
\end{tabular}

Robust standard errors in brackets. ${ }^{* * *} \mathrm{p}<0.01,{ }^{* *} \mathrm{p}<0.05{ }^{*} \mathrm{p}<0.1$.

+ denotes imputed variable 
Table 10: Regressions: Total Financial Wealth and Occupation

\begin{tabular}{|c|c|c|c|c|c|c|}
\hline & (1) & (2) & (3) & $(4)$ & (5) & (6) \\
\hline Dependent Variable: & \multicolumn{6}{|c|}{ In (Total Financial Wealth) } \\
\hline \multicolumn{7}{|c|}{ Financial Occupation (=1 for HH if either individual =1): } \\
\hline Budget & & $\begin{array}{c}0.175 \\
{[0.281]}\end{array}$ & & & & \\
\hline Math & & & $\begin{array}{c}0.0503 \\
{[0.262]}\end{array}$ & & & \\
\hline Finance & & & & $\begin{array}{c}0.379 \\
{[0.393]}\end{array}$ & & \\
\hline Composite Indicator & & & & & $\begin{array}{c}0.221 \\
{[0.278]}\end{array}$ & \\
\hline Lower Bar Indicator & & & & & & $\begin{array}{c}0.608 \\
{[0.429]}\end{array}$ \\
\hline $\begin{array}{l}\text { In(Lifetime HH } \\
\text { earnings) }\end{array}$ & $\begin{array}{c}1.681 * * \\
{[0.764]}\end{array}$ & $\begin{array}{c}1.653 * * \\
{[0.778]}\end{array}$ & $\begin{array}{c}1.678 * * \\
{[0.773]}\end{array}$ & $\begin{array}{c}1.664 * * \\
{[0.765]}\end{array}$ & $\begin{array}{c}1.635 * * \\
{[0.786]}\end{array}$ & $\begin{array}{l}1.564 * * \\
{[0.766]}\end{array}$ \\
\hline Number Series Score & $\begin{array}{c}0.373^{*} \\
{[0.219]}\end{array}$ & $\begin{array}{c}0.368 * \\
{[0.219]}\end{array}$ & $\begin{array}{c}0.372^{*} \\
{[0.219]}\end{array}$ & $\begin{array}{c}0.364^{*} \\
{[0.220]}\end{array}$ & $\begin{array}{c}0.363^{*} \\
{[0.220]}\end{array}$ & $\begin{array}{c}0.34 \\
{[0.217]}\end{array}$ \\
\hline $\begin{array}{l}\text { \# Econ Courses (HH } \\
\text { max) }\end{array}$ & $\begin{array}{c}0.00399 \\
{[0.0934]}\end{array}$ & $\begin{array}{l}-0.00427 \\
{[0.0976]}\end{array}$ & $\begin{array}{c}0.00353 \\
{[0.0944]}\end{array}$ & $\begin{array}{l}-0.0159 \\
{[0.103]}\end{array}$ & $\begin{array}{r}-0.00503 \\
{[0.0966]}\end{array}$ & $\begin{array}{r}-0.00758 \\
{[0.0950]}\end{array}$ \\
\hline Age (max in $\mathbf{H H})$ & $\begin{array}{c}0.0391 * * \\
{[0.0172]}\end{array}$ & $\begin{array}{c}0.0387 * * \\
{[0.0171]}\end{array}$ & $\begin{array}{c}0.0390 * * \\
{[0.0172]}\end{array}$ & $\begin{array}{c}0.0389 * * \\
{[0.0171]}\end{array}$ & $\begin{array}{c}0.0385^{* *} \\
{[0.0171]}\end{array}$ & $\begin{array}{c}0.0321 * * \\
{[0.0161]}\end{array}$ \\
\hline Male education & $\begin{array}{l}0.225 * * \\
{[0.111]}\end{array}$ & $\begin{array}{l}0.224 * * \\
{[0.109]}\end{array}$ & $\begin{array}{c}0.225 * * \\
{[0.110]}\end{array}$ & $\begin{array}{c}0.225 * * \\
{[0.111]}\end{array}$ & $\begin{array}{c}0.221 * * \\
{[0.108]}\end{array}$ & $\begin{array}{l}0.216 * * \\
{[0.105]}\end{array}$ \\
\hline Female education & $\begin{array}{c}0.162 * \\
{[0.0873]}\end{array}$ & $\begin{array}{c}0.162 * \\
{[0.0868]}\end{array}$ & $\begin{array}{c}0.162 * \\
{[0.0871]}\end{array}$ & $\begin{array}{c}0.162 * \\
{[0.0869]}\end{array}$ & $\begin{array}{c}0.160 * \\
{[0.0859]}\end{array}$ & $\begin{array}{c}0.148 * \\
{[0.0807]}\end{array}$ \\
\hline Single indicator & $\begin{array}{l}3.074 * * \\
{[1.475]}\end{array}$ & $\begin{array}{l}3.039 * * \\
{[1.454]}\end{array}$ & $\begin{array}{c}3.069 * * \\
{[1.473]}\end{array}$ & $\begin{array}{l}3.086 * * \\
{[1.475]}\end{array}$ & $\begin{array}{c}3.009 * * \\
{[1.447]}\end{array}$ & $\begin{array}{l}2.949 * * \\
{[1.398]}\end{array}$ \\
\hline Constant & $\begin{array}{l}-20.12^{*} \\
{[11.15]}\end{array}$ & $\begin{array}{c}-19.69 * \\
{[11.28]} \\
\end{array}$ & $\begin{array}{c}-20.06^{*} \\
{[11.28]} \\
\end{array}$ & $\begin{array}{c}-19.89 * \\
{[11.13]} \\
\end{array}$ & $\begin{array}{c}-19.39 * \\
{[11.39]} \\
\end{array}$ & $\begin{array}{c}-18.05 \\
{[11.00]}\end{array}$ \\
\hline Observations & 495 & 495 & 495 & 495 & 495 & 495 \\
\hline R-squared & 0.187 & 0.187 & 0.187 & 0.188 & 0.188 & 0.193 \\
\hline
\end{tabular}


Table 11: Regressions: Stock Ownership and Occupation

\begin{tabular}{|c|c|c|c|c|c|c|}
\hline & (1) & (2) & (3) & (4) & (5) & (6) \\
\hline Dependent Variable: & \multicolumn{6}{|c|}{ Holds any stock or stock mutual funds (0/1) } \\
\hline \multicolumn{7}{|c|}{ Financial Occupation (=1 for HH if either individual =1): } \\
\hline Budget & & $\begin{array}{l}0.148^{* *} \\
{[0.0624]}\end{array}$ & & & & \\
\hline Math & & & $\begin{array}{l}-0.0389 \\
{[0.0893]}\end{array}$ & & & \\
\hline Finance & & & & $\begin{array}{c}0.121 \\
{[0.0818]}\end{array}$ & & \\
\hline Composite Indicator & & & & & $\begin{array}{l}0.133 * * \\
{[0.0606]}\end{array}$ & \\
\hline Lower Bar Indicator & & & & & & $\begin{array}{c}0.0982 \\
{[0.0616]}\end{array}$ \\
\hline $\begin{array}{l}\ln (\text { Lifetime HH } \\
\text { earnings) }\end{array}$ & $\begin{array}{c}0.240 * * * \\
{[0.0679]}\end{array}$ & $\begin{array}{l}0.216 * * * \\
{[0.0663]}\end{array}$ & $\begin{array}{l}0.243 * * * \\
{[0.0682]}\end{array}$ & $\begin{array}{c}0.234 * * * \\
{[0.0671]}\end{array}$ & $\begin{array}{l}0.212 * * * \\
{[0.0672]}\end{array}$ & $\begin{array}{l}0.221 * * * \\
{[0.0661]}\end{array}$ \\
\hline Number Series Score & $\begin{array}{l}0.0621 * \\
{[0.0343]}\end{array}$ & $\begin{array}{l}0.0584 * \\
{[0.0326]}\end{array}$ & $\begin{array}{l}0.0628 * \\
{[0.0344]}\end{array}$ & $\begin{array}{l}0.0595^{*} \\
{[0.0348]}\end{array}$ & $\begin{array}{l}0.0566^{*} \\
{[0.0329]}\end{array}$ & $\begin{array}{l}0.0569 * \\
{[0.0339]}\end{array}$ \\
\hline $\begin{array}{l}\text { \# Econ Courses (HH } \\
\text { max) }\end{array}$ & $\begin{array}{l}0.0217 * * \\
{[0.00977]}\end{array}$ & $\begin{array}{c}0.0147 \\
{[0.0100]}\end{array}$ & $\begin{array}{c}0.0220 * * \\
{[0.00983]}\end{array}$ & $\begin{array}{c}0.0153 \\
{[0.0113]}\end{array}$ & $\begin{array}{c}0.0162 \\
{[0.00988]}\end{array}$ & $\begin{array}{l}0.0198 * * \\
{[0.00969]}\end{array}$ \\
\hline Age (max in $\mathbf{H H})$ & $\begin{array}{c}-0.00435 \\
{[0.00303]}\end{array}$ & $\begin{array}{l}-0.00466 \\
{[0.00300]}\end{array}$ & $\begin{array}{c}-0.0043 \\
{[0.00304]}\end{array}$ & $\begin{array}{c}-0.00439 \\
{[0.00303]}\end{array}$ & $\begin{array}{c}-0.00471 \\
{[0.00301]}\end{array}$ & $\begin{array}{l}-0.00548 * \\
{[0.00301]}\end{array}$ \\
\hline Male education & $0.0240 * *$ & $0.0226 * *$ & $0.0243 * *$ & $0.0241 * *$ & $0.0216 * *$ & $0.0225 * *$ \\
\hline & $\begin{array}{c}{[0.00977]} \\
0.0290 * *\end{array}$ & $\begin{array}{c}{[0.00952]} \\
0.0285^{* *}\end{array}$ & $\begin{array}{c}{[0.00968]} \\
0.0293^{* *}\end{array}$ & $\begin{array}{c}{[0.00968]} \\
0.0290^{* *}\end{array}$ & $\begin{array}{c}{[0.00957]} \\
0.0275^{* *}\end{array}$ & $\begin{array}{c}{[0.00968]} \\
0.0267 * *\end{array}$ \\
\hline Female education & $\begin{array}{c}* \\
{[0.00899]}\end{array}$ & $\begin{array}{c}* \\
{[0.00851]}\end{array}$ & $\begin{array}{c}* \\
{[0.00885]}\end{array}$ & $\begin{array}{c}* \\
{[0.00900]}\end{array}$ & $\begin{array}{c}* \\
{[0.00863]}\end{array}$ & $\begin{array}{c}* \\
{[0.00893]}\end{array}$ \\
\hline Single indicator & $\begin{array}{c}0.491 * * * \\
{[0.136]}\end{array}$ & $\begin{array}{c}0.461 * * * \\
{[0.133]}\end{array}$ & $\begin{array}{c}0.494^{* * *} \\
{[0.135]}\end{array}$ & $\begin{array}{c}0.494 * * * \\
{[0.134]}\end{array}$ & $\begin{array}{c}0.451 * * * \\
{[0.133]}\end{array}$ & $\begin{array}{c}0.470 * * * \\
{[0.136]}\end{array}$ \\
\hline Constant & $\begin{array}{c}-3.393 * * * \\
{[0.990]}\end{array}$ & $\begin{array}{c}-3.027 * * * \\
{[0.969]}\end{array}$ & $\begin{array}{c}-3.442^{* * *} \\
{[0.991]}\end{array}$ & $\begin{array}{c}-3.318 * * * \\
{[0.979]}\end{array}$ & $\begin{array}{c}-2.950 * * * \\
{[0.978]}\end{array}$ & $\begin{array}{c}-3.059 * * * \\
{[0.974]}\end{array}$ \\
\hline Observations & 495 & 495 & 495 & 495 & 495 & 495 \\
\hline R-squared & 0.183 & 0.197 & 0.183 & 0.188 & 0.195 & 0.19 \\
\hline
\end{tabular}

Robust standard errors in brackets. ${ }^{* * *} \mathrm{p}<0.01,{ }^{* *} \mathrm{p}<0.05$, ${ }^{*} \mathrm{p}<0.1$.

+ denotes imputed variable 
Table 12: Descriptive statistics: Sample of HRS married couples in $2004^{\mathrm{a}}$

\begin{tabular}{|c|c|c|}
\hline Finance Occupation Indicators & Mean & Std. Dev. \\
\hline Budget - Husband (\%) & 0.16 & $(0.37)$ \\
\hline Budget - Wife (\%) & 0.11 & $(0.31)$ \\
\hline Budget - Household (\%) & 0.24 & $(0.43)$ \\
\hline Finance - Husband (\%) & 0.06 & $(0.24)$ \\
\hline Finance - Wife (\%) & 0.05 & $(0.22)$ \\
\hline Finance - Household (\%) & 0.11 & $(0.31)$ \\
\hline Math - Husband (\%) & 0.03 & $(0.18)$ \\
\hline Math - Wife (\%) & 0.01 & $(0.09)$ \\
\hline Math - Household (\%) & 0.04 & $(0.20)$ \\
\hline Lower Bar Indicator- Husband (\%) & 0.32 & $(0.47)$ \\
\hline Lower Bar Indicator - Wife (\%) & 0.32 & $(0.47)$ \\
\hline Lower Bar Indicator - HH (\%) & 0.51 & $(0.50)$ \\
\hline Composite Indicator - Husband (\%) & 0.19 & $(0.39)$ \\
\hline Composite Indicator - Wife (\%) & 0.12 & $(0.32)$ \\
\hline Composite Indicator - HH (\%) & 0.27 & $(0.45)$ \\
\hline \multicolumn{3}{|l|}{ Wealth and Lifetime Earnings } \\
\hline $\ln (\mathrm{HH}$ wealth) & 11.98 & $(1.55)$ \\
\hline $\ln$ (Lifetime Earnings of Husband) & 12.58 & $(4.46)$ \\
\hline $\ln$ (Lifetime Earnings of Wife) & 10.71 & $(5.4)$ \\
\hline \multicolumn{3}{|l|}{ Other Control Variables } \\
\hline Husband's Age & 62.95 & $(5.43)$ \\
\hline Wife's Age & 58.98 & $(5.61)$ \\
\hline Husband's Education (in years) & 12.86 & $(3.32)$ \\
\hline Wife's Education (in years) & 12.76 & $(2.96)$ \\
\hline Ever Self-Employed - Husband & 0.24 & $(0.42)$ \\
\hline Ever Self-Employed - Wife & 0.15 & $(0.36)$ \\
\hline
\end{tabular}

a.n $=2,534$.

Notes: All occupation indicators for husband and wife are equal to one if the spouse's longest held occupation was categorized as dealing with budgets, high financial, or high math ${ }_{2}$ and zero otherwise. The household occupation indicators equal one if either spouse's longest held occupation was categorized as such. 
Table 13: Occupational Spillovers and Wealth - HRS sample

\begin{tabular}{|c|c|c|c|c|c|}
\hline \multirow{2}{*}{$\begin{array}{l}\text { Dependent Variable: } \\
\text { Financial Occ.: Budget - Husband }\end{array}$} & \multicolumn{5}{|c|}{ In[total HH wealth] } \\
\hline & $\begin{array}{c}0.200^{* *} \\
{[0.092]}\end{array}$ & & & & \\
\hline Financial Occ.: Budget - Wife & $\begin{array}{c}0.264 * * * \\
{[0.079]}\end{array}$ & & & & \\
\hline Financial Occ.: Finance - Husband & & $\begin{array}{c}0.159 \\
{[0.108]}\end{array}$ & & & \\
\hline Financial Occ.: Finance - Wife & & $\begin{array}{c}0.141 \\
{[0.104]}\end{array}$ & & & \\
\hline Financial Occ.: Math - Husband & & & $\begin{array}{c}0.07 \\
{[0.112]}\end{array}$ & & \\
\hline Financial Occ.: Math - Wife & & & $\begin{array}{c}0.257 \\
{[0.213]}\end{array}$ & & \\
\hline Finance Occ Indicator - Husband & & & & $\begin{array}{l}0.201 * * \\
{[0.082]}\end{array}$ & \\
\hline Finance Occ Indicator - Wife & & & & $\begin{array}{c}0.245^{* * *} \\
{[0.076]}\end{array}$ & \\
\hline Lower Bar Finance Occ. - Husband & & & & & $\begin{array}{c}0.218 * * * \\
{[0.071]}\end{array}$ \\
\hline Lower Bar Finance Occ. - Wife & & & & & $\begin{array}{c}0.223^{* * *} \\
{[0.063]}\end{array}$ \\
\hline In[Lifetime Earnings for $\mathbf{H H}]$ & $\begin{array}{c}0.452 * * * \\
{[0.090]}\end{array}$ & $\begin{array}{c}0.466^{* * * *} \\
{[0.091]}\end{array}$ & $\begin{array}{c}0.470 * * * \\
{[0.092]}\end{array}$ & $\begin{array}{c}0.448 * * * \\
{[0.09]}\end{array}$ & $\begin{array}{c}0.451 * * * \\
{[0.091]}\end{array}$ \\
\hline Lifetime Earn. = 0 for Husband or Wife [0/1] & $\begin{array}{c}0.339 * * * \\
{[0.096]}\end{array}$ & $\begin{array}{c}0.325 * * * \\
{[0.096]}\end{array}$ & $\begin{array}{c}0.325 * * * \\
{[0.096]}\end{array}$ & $\begin{array}{c}0.344 * * * \\
{[0.097]}\end{array}$ & $\begin{array}{c}0.403^{* * *} \\
{[0.100]}\end{array}$ \\
\hline Ever Self-Employed - Husband & $\begin{array}{c}0.516 * * * \\
{[0.084]}\end{array}$ & $\begin{array}{c}0.534 * * * \\
{[0.088]}\end{array}$ & $\begin{array}{c}0.544 * * * \\
{[0.088]}\end{array}$ & $\begin{array}{c}0.514 * * * \\
{[0.085]}\end{array}$ & $\begin{array}{c}0.518 * * * \\
{[0.086]}\end{array}$ \\
\hline Ever Self-Employed - Wife & $\begin{array}{c}0.278 * * * \\
{[0.089]}\end{array}$ & $\begin{array}{c}0.296 * * * \\
{[0.090]}\end{array}$ & $\begin{array}{c}0.295 * * * \\
{[0.089]}\end{array}$ & $\begin{array}{c}0.281^{* * *} \\
{[0.088]}\end{array}$ & $\begin{array}{c}0.278^{* * *} \\
{[0.089]}\end{array}$ \\
\hline Husband's Age & $\begin{array}{c}0.025 * * * \\
{[0.007]}\end{array}$ & $\begin{array}{c}0.026 * * * \\
{[0.007]}\end{array}$ & $\begin{array}{c}0.026 * * * \\
{[0.007]}\end{array}$ & $\begin{array}{c}0.025^{* * *} \\
{[0.007]}\end{array}$ & $\begin{array}{c}0.025^{* * *} \\
{[0.007]}\end{array}$ \\
\hline Wife's Age & $\begin{array}{c}0.016 * * \\
{[0.007]}\end{array}$ & $\begin{array}{c}0.016 * * \\
{[0.007]}\end{array}$ & $\begin{array}{c}0.017 * * \\
{[0.007]}\end{array}$ & $\begin{array}{c}0.016 * * \\
{[0.007]}\end{array}$ & $\begin{array}{c}0.016 * * \\
{[0.007]}\end{array}$ \\
\hline Husband's Education & $\begin{array}{c}0.098 * * * \\
{[0.021]}\end{array}$ & $\begin{array}{c}0.101^{* * *} \\
{[0.020]}\end{array}$ & $\begin{array}{c}0.103 * * * \\
{[0.020]}\end{array}$ & $\begin{array}{c}0.098 * * * \\
{[0.02]}\end{array}$ & $\begin{array}{c}0.097 * * * \\
{[0.020]}\end{array}$ \\
\hline Wife's Education & $\begin{array}{c}0.104^{* * *} \\
{[0.014]}\end{array}$ & $\begin{array}{c}0.107 * * * \\
{[0.014]}\end{array}$ & $\begin{array}{c}0.107 * * * \\
{[0.014]}\end{array}$ & $\begin{array}{c}0.102 * * * \\
{[0.014]}\end{array}$ & $\begin{array}{c}0.097 * * * \\
{[0.014]}\end{array}$ \\
\hline Constant & $\begin{array}{c}0.076 \\
{[1.332]}\end{array}$ & $\begin{array}{c}-0.213 \\
{[1.345]}\end{array}$ & $\begin{array}{c}-0.32 \\
{[1.346]}\end{array}$ & $\begin{array}{c}0.149 \\
{[1.336]}\end{array}$ & $\begin{array}{c}0.186 \\
{[1.334]}\end{array}$ \\
\hline Observations & 2534 & 2534 & 2534 & 2534 & 2534 \\
\hline R-squared & 0.247 & 0.243 & 0.242 & 0.247 & 0.25 \\
\hline
\end{tabular}

All regressions are weighted using the HRS household weights. Robust standard errors in parentheses.

*** $\mathrm{p}<0.01,{ }^{* *} \mathrm{p}<0.05, * \mathrm{p}<0.1$ 


\section{Appendix A: Financial Knowledge Measurement}

\section{Components of "Attitudinal" Financial Knowledge Measure}

\section{True/False Questions (100\% "Surely True" to 100\% "Surely False", 12-point scale)}

True Version

Q18 Financially, investing in the stock market is better than buying lottery tickets.

Q21 The more you diversify among stocks, the more of your money you can invest in stocks.

Q23 Young people should hold somewhat riskier financial investments than older people.

Q25 Even if you are smart, it is hard to pick individual company stocks that will have better than average returns.

Q28 It is possible to invest in the stock market in a way that makes it hard for people to take unfair advantage of you.

Q31 An employee of a company with publicly traded stock should have little or none of his or her retirement savings in the company's stock.

Q33 It is a good idea to own stocks of foreign companies.

Q34 Even older retired people should hold some stocks.

Q38 It is important to take a look at your investments periodically to see if you need to make changes.

Q39 It is better for young people saving for retirement to combine stocks with long-term (inflation protected) bonds than with shortterm (inflation protected) bonds.

Q41 Buying a stock mutual fund usually provides a safer return than a single company stock.
False Version

Financially, investing in the stock market is no better than buying lottery tickets. The more you diversify among stocks, the less of your money you should invest in stocks.

Older people should hold somewhat riskier financial investments than young people. If you are smart, it is easy to pick individual company stocks that will have better than average returns.

There is no way to avoid people taking advantage of you if you try to invest in the stock market.

An employee of a company with publicly traded stock should have a lot of his or her retirement savings in the company's stock. It is best to avoid owning stocks of foreign companies.

Older retired people should not hold any stocks.

Once you have made an initial decision about the investment mix for your portfolio, you should avoid making changes to your portfolio until you are close to retirement. It is better for young people saving for retirement to combine stocks with shortterm (inflation protected) bonds than with long-term (inflation protected) bonds. Buying a single company stock usually provides a safer return than a stock mutual fund. 
Multiple-choice questions (score is one if correct, zero if incorrect; correct answers in bold font)

Q15 Suppose you had \$100 in a savings account and the interest rate was $2 \%$ per year. After 5 years, how much do you think you would have in the account if you left the money to grow? Answer options: More than \$102; Exactly \$102; Less than \$102.

Q16 Imagine that the interest rate on your savings account was 1\% per year and inflation was 2\% per year. After 1 year, would you be able to buy more than, exactly the same as, or less than today with the money in this account?

Answer options: More than today; Exactly the same as today; Less than today.

\section{Components of "Factual" Financial Knowledge Measure (continued)}

True/False Questions (100\% "Surely True" to 100\% "Surely False", 12-point scale)

\begin{tabular}{|c|c|c|}
\hline & True Version & False Version \\
\hline Q17 & $\begin{array}{l}\text { An investment advisor tells a } 30 \text {-year-old } \\
\text { couple that } \$ 1,000 \text { in an investment that pays a } \\
\text { certain, constant interest rate would double in } \\
\text { value to } \$ 2,000 \text { after } 20 \text { years (by the time they } \\
\text { are } 50 \text { ). If so, that investment would be worth } \\
\$ 4,000 \text { after } 40 \text { years (by the time they are } 70 \text { ). }\end{array}$ & $\begin{array}{l}\text { An investment advisor tells a } 30 \text {-year-old } \\
\text { couple that } \$ 1,000 \text { in an investment that } \\
\text { pays a certain, constant interest rate would } \\
\text { double in value to } \$ 2,000 \text { after } 20 \text { years (by } \\
\text { the time they are } 50 \text { ). If so, that investment } \\
\text { would not be worth } \$ 4,000 \text { for at least } 45 \\
\text { years (until they are at least } 75 \text { ). }\end{array}$ \\
\hline Q19 & $\begin{array}{l}\text { When an investor spreads money between } 20 \\
\text { stocks, rather than } 2 \text {, the risk of losing a lot of } \\
\text { money decreases. }\end{array}$ & $\begin{array}{l}\text { When an investor spreads money between } \\
20 \text { stocks, rather than 2, the risk of losing a } \\
\text { lot of money increases. }\end{array}$ \\
\hline Q20 & $\begin{array}{l}\text { If you start out with } \$ 1,000 \text { and earn an } \\
\text { average return of } 10 \% \text { per year for } 30 \text { years, } \\
\text { after compounding, the initial } \$ 1,000 \text { will have } \\
\text { grown to more than } \$ 6,000 \text {. }\end{array}$ & $\begin{array}{l}\text { If you start out with } \$ 1,000 \text { and earn an } \\
\text { average return of } 10 \% \text { per year for } 30 \text { years, } \\
\text { even after compounding, the initial } \$ 1,000 \\
\text { will have grown to less than } \$ 6,000 \text {. }\end{array}$ \\
\hline Q22 & $\begin{array}{l}\text { Mutual funds do not pay a guaranteed rate of } \\
\text { return. }\end{array}$ & $\begin{array}{l}\text { Mutual funds pay a guaranteed rate of } \\
\text { return. }\end{array}$ \\
\hline Q24 & $\begin{array}{l}\text { It is easy to find mutual funds that have annual } \\
\text { fees of less than one percent of assets. }\end{array}$ & $\begin{array}{l}\text { It is hard to find mutual funds that have } \\
\text { annual fees of less than one percent of } \\
\text { assets. }\end{array}$ \\
\hline Q26 & $\begin{array}{l}\text { Using money in a bank savings account to pay } \\
\text { off credit card debt is usually a good idea. }\end{array}$ & $\begin{array}{l}\text { Using money in a bank savings account to } \\
\text { pay off credit card debt is usually a bad } \\
\text { idea. }\end{array}$ \\
\hline Q27 & $\begin{array}{l}\text { You could save money in interest costs by } \\
\text { choosing a 15-year rather than a } 30 \text {-year } \\
\text { mortgage. }\end{array}$ & $\begin{array}{l}\text { You could save money in interest costs by } \\
\text { choosing a } 30 \text {-year rather than a } 15 \text {-year } \\
\text { mortgage. }\end{array}$ \\
\hline Q29 & If the interest rate falls, bond prices will rise. & If the interest rate falls, bond prices will fall. \\
\hline Q30 & $\begin{array}{l}\text { Taxes affect how you should invest your } \\
\text { money. }\end{array}$ & $\begin{array}{l}\text { Taxes do not affect how you should invest } \\
\text { your money. }\end{array}$ \\
\hline Q32 & $\begin{array}{l}\text { For a family with a working husband and a } \\
\text { wife staying home to take care of their young } \\
\text { children, life insurance that will replace three } \\
\text { years of income is not enough life insurance. }\end{array}$ & $\begin{array}{l}\text { For a family with a working husband and a } \\
\text { wife staying home to take care of their } \\
\text { young children, life insurance that will } \\
\text { replace three years of income is more than } \\
\text { enough. }\end{array}$ \\
\hline
\end{tabular}


Q35 You should invest in either mutual funds or a large number of different stocks instead of just a few stocks.

Q36 To make money in the stock market, you should not buy and sell stocks too often.

Q37 If you have to sell one of your stocks you should sell one that has gone down in price rather than one which has gone up.

Q40 If you invest for the long run, the annual fees of mutual funds are important.
You should invest most of your money in a few good stocks that you select rather than in lots of stocks or in mutual funds.

To make money in the stock market, you have to buy and sell stocks often.

If you have to sell one of your stocks you should sell one that has gone up in price rather than one which has gone down. If you invest for the long run, the annual fees of mutual funds are unimportant. 


\section{Appendix B: Lifetime Earnings Measures}

We compile data from Social Security Administration detailed and summary earnings files in order to have annual earnings for each linked HRS respondent from $1951^{18}$ to $2004{ }^{19}$ We exclude respondents for whom we have less than 25 years of earnings. ${ }^{20}$ For the remaining sample, we impute yearly earnings in cases where a) the respondents had not yet attained age 65 and b) we first observe the respondent at an age later than 18. In both cases, we use a regression based hotdeck method of imputation where earnings are predicted based on age, tenure on longest job, actual work experience, education, race, gender, and occupation. Observations are then sorted based on the predicted earnings and individuals with missing earnings are assigned the earnings from a nearest neighbor. Finally, we calculate the lifetime earnings as the present value of earnings summed from age 18 to 65 (in year 2004 dollars).

We impute lifetime earnings values to individuals in our CogEcon sample from the HRSA-SSA data using the 3 digit occupation by education (college versus no college) by gender cell medians. In a few cases, these cell sizes are too small, so we use 2 digit occupation cell medians.

\footnotetext{
${ }^{18} 1951$ is the earliest year of earnings records available in the SSA restricted data linked to HRS.

${ }^{19}$ The HRS-SSA earnings records linking process is not straightforward. Respondents were consented at several different points. The original HRS entry cohort was consented in 1992 and then re-consented in 2004. Individuals in the CODA and WB cohorts were consented in 1998 and the EBB cohort was consented in 2004.

${ }^{20}$ We deal with SS tax caps partially. From 1978-1993 we have detailed earnings measures, including the Medicare earnings. Because there was no Medicare cap after 1993, we use a nearest neighbor hotdeck imputation from that subsample to replace capped earnings for 1978-1993.
} 